\title{
Predicting soil salinity in response to different irrigation practices, soil types and rainfall scenarios
}

Daniel Isidoro ${ }^{1}$ and S. R. Grattan ${ }^{2}$

${ }^{1}$ Unidad de Suelos y Riegos (asociada al CSIC), Centro de Investigación y Tecnología Agroalimentaria de Aragón (CITA-DGA), Zaragoza, Spain

E-mail: disidoro@aragon.es

Telephone: ++ (34) 976716802

Fax: ++ (34) 976716335

${ }^{2}$ Department of Land, Air and Water Resources (LAWR), University of California, Davis, CA USA

\section{Keywords}

Drainage, electrical conductivity (EC), irrigation, leaching fraction, modeling, salt balance, soil salinity, water balance

\begin{abstract}
A model was developed to predict rootzone salinity under different irrigation practices on different soil types, with similar rainfall but different monthly distributions. A rootzone daily water and salt balance was performed using eight scenarios: two soil types (coarse-textured v. fine-textured), two multi-year series of actual rainfall data and two irrigation practices (surface with fixed number of irrigations and ET-based sprinkler irrigation). All factors influenced the mean electrical conductivity (EC) of the rootzone in the growing season $\left(\mathrm{EC}_{\mathrm{eS}}\right)$ : (i) Surface irrigation led to lower $\mathrm{EC}_{\mathrm{eS}}$ than sprinkler irrigation; (ii) Winterconcentrated rainfall caused lower $\mathrm{EC}_{\mathrm{eS}}$ than rainfall distributed uniformly throughout the year; and (iii) Coarser textured soil usually resulted in lower $\mathrm{EC}_{\mathrm{es}}$ than the finer textured. The $\mathrm{EC}_{\mathrm{eS}}$ was related to the total precipitation of the hydrologic year and to the annual leaching fraction (LF), but surprisingly not to the seasonal LF. In most cases the model predicted lower $\mathrm{EC}_{\mathrm{es}}$ than the FAO steady-state approach. Therefore considering these site-specific features could lead to lower leaching requirements and the safe use of higher salinity water.
\end{abstract}




\section{Introduction}

Irrigation is essential in arid and semi-arid climates to optimize crop production but it unavoidably leads to off-site environmental problems such as higher salinity of irrigation return flows (Tanji and Kielen 2002) and increases in nutrient, pesticide and sediment loads (Ongley 1996) resulting in the deterioration of water quality. At the same time, irrigation can have on-site effects such as waterlogging, salinization and sodification of agricultural lands (Skaggs and van Shilfgaarde 1999).

In the context of global competition for water resources, there is a need to understand the complex dynamics of water management including crop evapotranspiraton (ET), water quality and leaching requirements, all of which depend upon site-specific conditions (i.e. crop type, irrigation method, climate, and soil type). This site-specific determination of water needs and required water quality would improve large scale water management and policy decisions.

Soil salinity has been predicted as a function of the salinity of the irrigation water and the leaching fraction in the traditional steady-state model described in FAO 29 (Ayers and Westcot 1985; Rhoades et al. 1992). While this model is a good first approximation, it does not account for soil properties, rainfall patterns or various climates where ET changes throughout the year. These factors will have a profound influence on soil salinity throughout the crop season (Ayers and Westcot 1985). The irrigation method is only considered in FAO 29 by assigning different root-water uptake patterns in relation to high frequency and conventional irrigation and by assuming that the electrical conductivity (EC) of the soil solution must be weighted to account for root-water uptake in high frequency irrigation systems (Ayers and Westcot 1985).

Many steady- and transient-state models (ranging in complexity from bucket-type to numerical solutions of the Richards equation) have been used to model water movement through the soil and associated processes of crop uptake and solute movement (Bastiaansen et al. 2007). Letey and Feng (2007) concluded that steady-state models tend to overestimate the adverse effects of irrigating with saline waters, thus pointing to water quality standards for salinity higher than necessary. The same results were found by Corwin et al. (2007), but they also found that in some instances, accounting for salt precipitation-dissolution processes may be more important than using a dynamic model. Both papers agree in the benefits of using 
transient-models to estimate leaching requirements (and thus irrigation volumes) and to develop irrigation management guidelines.

However, sophisticated transient-state models often require highly trained modeling experts and input data are sometimes difficult to obtain. There are also issues with spatial variability that limits the application of the models on a large-scale basis for management purposes (Bastiaansen et al. 2007). Therefore, the use of advanced models for management purposes may need the development of less data-intensive and more user-friendly transient models (Bastiaansen et al. 2007).

A simple, daily time-step soil salinity model, based on soil water storage in four rootzone quarters was developed and applied to long records of meteorological data to take into account a number of site-specific factors. The objectives of this paper were: (i) to develop a straightforward water and salt balance model based on available data (meteorological daily records, crop evapotranspiration (ET) and soil textural parameters) that could be used by regulators to set water quality criteria for electrical conductivity (or chloride); (ii) to incorporate local soil properties, rainfall patterns, crop type and type of irrigation into the model, and establish the effect of these factors on soil salinity during the growing season; (iii) to determine the influence of these site-specific parameters on irrigation water - soil salinity relations and (iv) to compare the results of the application of the model with the current, steady-state FAO 29 approach.

\section{Material and Methods}

\section{Model development}

The model we developed performs a water and salt balance in the root zone under similar root water-extraction assumptions to the Ayers and Westcot model. The root zone is divided in four quarters of equal depth and the water inputs and outputs in each layer are calculated on a daily basis (precipitation and temperature records for ET calculations that are widely available and that capture the temporal variability of the soil water processes) and the salt concentrations of each flow component are calculated assuming complete mixing and no chemical dissolution or precipitation of salts. While accounting for chemical dissolution and precipitation is valuable and would be an important addition to the model, this model expands on the FAO 29 approach, which is based on EC and evapoconcentration only and does not account for these processes.

Water Balance 
The inputs for the first quarter (top soil layer) are the applied irrigation (I) and rainfall (P), and the outputs, the drainage above field capacity (D, from layer 1 to layer 2), and evapotranspiration (ET) from the layer. For the underlying layers, the only input is the drainage (D) from the overlying layer and the outputs are the drainage to the underlying layer and ET from that layer. For the fourth quarter (deepest layer), the drainage represents the total drainage from the crop rootzone. Drainage was only allowed from a layer when its volumetric water content was higher than field capacity. Additionally, water flow at water contents below field capacity (U) was considered between layers and calculated in daily steps too. This unsaturated flow is related to the difference in the water content between the layers and is either upward or downward in direction depending upon the water potential gradient between adjacent layers.

Each soil layer was assigned a saturation water content (S), wilting point (WP), field capacity (FC) and total available water (TAW $=\mathrm{FC}-\mathrm{WP}$ ) according to the soil characteristics for the soil texture chosen. The volumetric water contents $\left(\theta_{\mathrm{S}}, \theta_{\mathrm{FC}}\right.$ and $\theta_{\mathrm{WP}}$ available for each soil layer or estimated from texture) were transformed to water contents (S, FC and WP in $\mathrm{mm}$ ) by multiplying the layer depth $\mathrm{RD} / 4$ and the fine earth fraction of the material, where $\mathrm{RD}$ (mm) was taken about $75-85 \%$ of the rooting depth for the modeled crop, the depth which is usually taken for salinity control and where most of the water uptake takes place (Ayers and Westcot 1985).

The daily $\mathrm{ET}_{\mathrm{c}}$ was calculated using appropriate data for $\mathrm{K}_{\mathrm{c}}$ and the duration of the crop stages (Goldhamer and Snyder 1989) and $\mathrm{ET}_{\mathrm{o}}$ data calculated by the Hargreaves formula (corrected by regression to match local Penman-Monteith estimates) (Hargreaves and Allen 2003): $E T_{\text {Har }}(m m / d)=0.0029 \cdot R_{a} \cdot\left(\mathrm{T}_{\mathrm{m}}\right) \cdot\left(\mathrm{T}_{\max }-\mathrm{T}_{\min }\right)^{0.4}$ where $\mathrm{T}_{\max }\left(\mathrm{T}_{\min }\right)$ was the maximum (minimum) daily temperature, $\mathrm{T}_{\mathrm{m}}$ was the mean daily temperature and the extraterrestrial

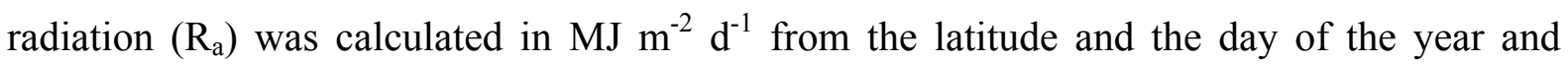
converted to $\mathrm{mm} / \mathrm{d}$ dividing by the latent heat of evaporation (Allen et al., 1998). These daily $\mathrm{ET}_{\mathrm{o}}$ estimates $\left(\mathrm{ET}_{\mathrm{Har}}\right)$ based on the Hargreaves formula were corrected by regression to match the $\mathrm{ET}_{\mathrm{o}}$ estimates by the Penman-Monteith method presented by Goldhamer and Snyder (1989). The model allows for the introduction of other linear regression coefficients specific to a location to convert $\mathrm{ET}_{\mathrm{Har}}$ estimates into locally more reliable $\mathrm{ET}_{\mathrm{o}}$ estimates.

The achievable, non water-stressed crop ET is calculated as $\mathrm{ET}_{\mathrm{c}}=\mathrm{K}_{\mathrm{c}} \cdot \mathrm{ET}_{\mathrm{o}}$. Between cropping seasons, all ET [or evaporation (E) since there is no established crop on the soil] was assumed to take place from the upper layer. For this period, the $\mathrm{K}_{\mathrm{c}}$ was calculated from 
the mean interval between precipitation (wetting) events of each month, the mean precipitation per event in each month and the $\mathrm{ET}_{\mathrm{o}}$ (Allen et al. 1998). The $\mathrm{K}_{\mathrm{c}}$ for the initial development stage (Stage 1) was also calculated in this way including irrigations to establish the interval between wetting events and mean irrigation or precipitation per event. During the non-growing season and the first stage of crop development, ET was reduced according to the soil water content of an upper evaporation layer (with user defined depth, always lower than first layer) calculated through the soil water balance following Allen et al. (1998).

The crop coefficients for the full development stage $\left(\mathrm{K}_{\mathrm{c} \text { mid, }}\right.$ Stage 3$)$ and for the end of the growing season $\left(\mathrm{K}_{\mathrm{c} \text { end }}\right)$ were taken from Goldhamer and Snyder (1989). For the crop development stage (Stage 2), $K_{c}$ was interpolated linearly between $K_{c}$ of the last day of the initial stage and $\mathrm{K}_{\mathrm{c} \text { mid }}$ (constant $\mathrm{K}_{\mathrm{c}}$ of Stage 3, full crop development). The $\mathrm{K}_{\mathrm{c}}$ was also interpolated linearly between $\mathrm{K}_{\mathrm{c} \text { mid }}$ and $\mathrm{K}_{\mathrm{c} \text { end }}$ for the late season stage (Stage 4).

Similar to the assumptions by Ayers and Westcot (1985), during the growing season the extraction pattern for each descending quarter-layer of the rootzone was taken as $40 \%-30 \%$ 20\%-10\% (usual pattern for long irrigation intervals or conventional irrigation). Therefore the achievable crop ET from layer " $\mathrm{k}$ " is $\mathrm{ET}_{\mathrm{c}}(\mathrm{k})=\mathrm{C}_{\mathrm{k}} \mathrm{ET}_{\mathrm{c}}$ where $\mathrm{C}_{1}=0.4, \mathrm{C}_{2}=0.3, \mathrm{C}_{3}=0.2$, and $\mathrm{C}_{4}=0.1$.

In each layer, the actual crop ET $\left[\mathrm{ET}_{\mathrm{r}}(\mathrm{k})\right]$ can be lower than $\mathrm{ET}_{\mathrm{c}}(\mathrm{k})$ due to water stress, which depends on the soil water content and the sensitivity of the crop to low water contents, accounted for through the crop-specific parameter $\mathrm{p}$ : the ratio of readily available soil water (RAW) to TAW ( $\mathrm{p}=\mathrm{RAW} / \mathrm{TAW}$ ) (Allen et al. 1998). When the soil water content [W(k)] in a layer fell below $\mathrm{We}(\mathrm{k})=\mathrm{WP}+(1-\mathrm{p}) \mathrm{TAW}$, the ET from that layer $\left[\mathrm{ET}_{\mathrm{r}}(\mathrm{k})\right]$ dropped below the $\mathrm{ET}_{\mathrm{c}}(\mathrm{k})$ and the actual ET of the layer was calculated as $\mathrm{ET}_{\mathrm{r}}(\mathrm{k})=\mathrm{K}_{\mathrm{s}} \cdot \mathrm{ET}_{\mathrm{c}}(\mathrm{k})$, where $\mathrm{K}_{\mathrm{s}}$ is a stress coefficient (Allen et al., 1998):

$$
K_{s}= \begin{cases}1 \ldots \ldots \ldots \ldots \ldots \ldots . & \text { if } \quad W(k)>W e(k) \\ \frac{W(k)-W e(k)}{W e(k)-W P(k)} & \text { if } \quad W P(k)<W(k)<W e(k) \\ 0 \ldots \ldots \ldots \ldots \ldots \ldots . . . & \text { if } \quad W(k)<W P(k)\end{cases}
$$

Also, when one layer was stressed during the growing season $[\mathrm{W}(\mathrm{k})<\mathrm{We}(\mathrm{k})]$ the model allowed to increase the extraction coefficient of the lower layer $\mathrm{C}_{\mathrm{k}+1}$ to supply the ET demand of the day; thus assuming that the crop can extract water from deeper soil layers when there was water stress in a given soil layer. 
When the soil water content in layer " $k$ " $[\mathrm{W}(\mathrm{k})]$ was above $\mathrm{FC}(\mathrm{k})$, the excess water $[\mathrm{Ex}(\mathrm{k})=\mathrm{W}(\mathrm{k})-\mathrm{FC}(\mathrm{k})]$ drains to the lower layer over a two-day period, so that $\mathrm{W}$ dropped to FC in two days and with higher flow in the first day than the second. The fraction " $\alpha$ " of the excess water that drained the first day $(0<\alpha<1)$ was calculated from the soil texture in the layer through an empirical relation obtained to match the results presented by Hillel and van Bavel (1976) for three soil types (approximately, $\alpha \sim 0.9$ for sand, $\alpha \sim 0.75$ for loam and $\alpha \sim 0.6$ for clay). For that purpose, two arbitrary water contents in excess of $\mathrm{FC}, \mathrm{Wa}$ and $\mathrm{Wb}$, were defined from the FC and saturation (S) of the soil layer and the fraction $\alpha$ : $W a=F C+(1-\alpha) \cdot(S-F C)<W b=F C+\frac{1-\alpha}{\alpha}(S-F C)$ and $\mathrm{D}$ is calculated as:

$$
D=\left\{\begin{array}{l}
\alpha \cdot(W-F C) \ldots \ldots \ldots \ldots \text { if } \quad W>W b \\
(1-\alpha) \cdot(S-F C) \ldots \ldots \text { if } \quad W a<W<W b \\
W-F C \ldots \ldots \ldots \ldots \ldots . \text { if } \quad W<W a
\end{array}\right.
$$

With the drainage (D) defined above, neither upward movement of water (redistribution of water throughout the profile) nor drainage with $\mathrm{W}<\mathrm{FC}$ were allowed. In order to account for the slow water movement between layers for low W, a slow upward/downward flow (U; dependent upon the difference in matric potential between soil layers) was introduced. This term was only considered when $\mathrm{W}<\mathrm{FC}+0.5 \cdot(\mathrm{Wa}-\mathrm{FC})$, so that when $\mathrm{W}$ was well above FC, water movement depended only on W. On the other hand, for lower W, water movement depended on the water content (matric potential) of adjacent layers and their soil properties. This term allowed for the redistribution of water in the profile, such as the wetting of the upper layer from lower layers when soil water is depleted by ET. The model allows the user to make use of $\mathrm{U}$ or not.

The term $U$ was defined empirically so that it can be inferred from the texture of the soil layers alone. For each textural class, representative values of $\mathrm{K}_{\mathrm{s}}$ were selected (Rawls and Brakensiek 1989; Clapp and Hornberger 1978) and simulations of water movement under varying differences of matric potential between layers (from FC in one layer to different $\mathrm{W}$ above WP in the other) were performed. For each of the simulations (performed with 10minute time steps and $10 \mathrm{~cm}$ distances between layers), the cumulative water flows after one day (the model time step: $\Delta \theta_{1 \text { day }}$ ) were expressed as a fraction of the total difference in water content $(x)$ at the beginning of the simulation, where $x=\left(\Delta \theta_{1 \text { day }}\right) /\left(\theta_{1}-\theta_{2}\right)$ with $\theta_{1}$ and $\theta_{2}$ being the initial water contents in both simulation layers $\left(\theta_{1}=\theta_{\mathrm{FC}}\right.$ and $\left.\theta_{\mathrm{WP}}<\theta_{2}<\theta_{2 \mathrm{FC}}\right)$. With all the simulations performed, the logit regressions (Ashton 1972) between $\mathrm{x}$ and the clay (C) 
and sand (S) weight fractions of the soil and the difference in matric potential between the layers $\left(\Delta \psi=\psi_{1}-\psi_{2}\right.$ where $\psi_{1}$ and $\psi_{2}$ are the initial matric potentials in both layers in $\left.\mathrm{cm}\right)$ are fitted. The fitted logit regression yielded $\mathrm{x}$ as a linear function of $\mathrm{C}, \mathrm{S}$ and $\Delta \psi$ :

$$
\mathrm{x}=1 /[1+\exp (0.489+0.00003 \Delta \psi+1.289 \mathrm{~S}+2.854 \mathrm{C})] ; \quad\left(\mathrm{R}^{2}=0.78\right) \quad \text { [Eq. 3] }
$$

always bound between 0 and $1(0<\mathrm{x}<1)$ so that the water transfer between two layers never reaches the difference in water content between the layers $\left(\theta_{1}-\theta_{2}\right)$, a problem found when applying the water movement equations to long one-day time steps.

To perform the aforementioned simulations, the soil matric potential $(\psi)$ was related to the volumetric water content $(\theta)$ by means of the equation (Clapp and Hornberger 1978):

$$
\psi=\psi_{S} \cdot\left(\theta / \theta_{S}\right)^{-b}
$$

where $\theta_{\mathrm{s}}$ was the volumetric water content at saturation, $\psi_{\mathrm{s}}$ is the water entry potential or "saturation" water potential, and $b$ is the slope of the water retention curve on a logarithmic plot. For each soil type, $b$ and $\psi_{\mathrm{s}}$ were calculated from the volumetric water content at field capacity and wilting point $\left(\theta_{\mathrm{FC}}\right.$ and $\left.\theta_{\mathrm{WP}}\right)$ and their respective potentials in absolute value $\left[\psi_{\mathrm{FC}}=316 \mathrm{~cm}\right.$ and $\psi_{\mathrm{WP}}=15849 \mathrm{~cm}$; so that $\mathrm{pF}(\mathrm{FC})=2.5$ and $\left.\mathrm{pF}(\mathrm{WP})=4.2\right]$. Taking logarithms, the expression of the potentials for FC and WP become linear equations

$$
\begin{aligned}
& \log \left(\psi_{F C}\right)=2.5=\log \psi_{S}-b \cdot \log \left(\theta_{F C} / \theta_{S}\right) \\
& \log \left(\psi_{W P}\right)=4.2=\log \psi_{S}-b \cdot \log \left(\theta_{W P} / \theta_{S}\right)
\end{aligned}
$$

from which $b$ and $\psi_{\mathrm{s}}$ are estimated. The unsaturated hydraulic conductivity for a given $\theta$ was given by (Clapp and Hornberger 1978)

$$
K=K_{S}\left(\theta / \theta_{S}\right)^{2 b+3}
$$

where $\mathrm{K}_{\mathrm{S}}$ is the saturated hydraulic conductivity (available for that layer material or estimated from texture). Thus, the flow between the layers (U) can be calculated as

$$
\mathrm{U}=\mathrm{K}(\Delta \psi / \Delta \mathrm{Z})
$$

where $\Delta \mathrm{Z}=10 \mathrm{~cm}$ (the distance selected for the simulations) neglecting the gravitational gradient.

Water is allowed to flow out of layer $4\left(\mathrm{U}_{4 \rightarrow}\right)$ by gravitational potential only, assuming that there were no water tables or impervious layers beneath that would affect drainage. The 
gravitational flow out of the root zone is taken as: $U_{4 \rightarrow}=K_{S}\left(\theta / \theta_{S}\right)^{2 b+3}$ where the parameters $\mathrm{K}_{\mathrm{S}}, \theta_{\mathrm{S}}$ and $b$ correspond to layer 4 and $\theta$ is the volumetric water content in layer 4 . Like $\mathrm{U}$, the model allows the option for including this low $\mathrm{W}$ flow out of the root zone.

All the water flows are assigned a plus sign when directed downwards (so that drainage is positive) and minus sign for upward flow. The $\mathrm{W}$ in a layer " $\mathrm{k}$ " on day $1(\mathrm{t}+1)\left[\mathrm{W}(\mathrm{k})_{1}\right.$ with $\mathrm{k}=1,2,3$, or 4 ] was calculated from the $\mathrm{W}$ in day 0 (or $\mathrm{t}) \mathrm{W}(\mathrm{k})_{0}$ and the water flows into and out of layer " $k$ " estimated on day 1 :

$$
\begin{aligned}
& \mathrm{W}(1)_{1}=\mathrm{W}(1)_{0}+\mathrm{I}(1)_{1}+\mathrm{P}(1)_{1}-\mathrm{D}(1)_{1}-\mathrm{ET}_{\mathrm{r}}(1)_{1}-\mathrm{U}(1)_{1} \\
& \mathrm{~W}(2)_{1}=\mathrm{W}(2)_{0}+\mathrm{D}(1)_{1}-\mathrm{D}(2)_{1}-\mathrm{ET}_{\mathrm{r}}(2)_{1}-\mathrm{U}(2)_{1} \\
& \mathrm{~W}(3)_{1}=\mathrm{W}(3)_{0}+\mathrm{D}(2)_{1}-\mathrm{D}(3)_{1}-\mathrm{ET}_{\mathrm{r}}(3)_{1}-\mathrm{U}(3)_{1} \\
& \mathrm{~W}(4)_{1}=\mathrm{W}(4)_{0}+\mathrm{D}(3)_{1}-\mathrm{D}(4)_{1}-\mathrm{ET}_{\mathrm{r}}(4)_{1}-\left(\mathrm{U}_{4 \rightarrow}\right)_{1}
\end{aligned}
$$

where the $\mathrm{D}$ is calculated with the $\mathrm{W}$ prior to $\mathrm{ET}_{\mathrm{r}}$ and $\mathrm{U}$ is calculated with the water content in the layers after all the other terms had been considered. The net drainage from a given layer " $\mathrm{k}$ " is obtained as $\mathrm{D}(\mathrm{k})+\mathrm{U}(\mathrm{k})$, and it is this value from layer 4 that is used as soil drainage in the results section.

Although preferential flow and irrigation non-uniformity are also important features that could be addressed empirically, these processes are complex and remain beyond the scope of this paper.

In addition, the model does not incorporate capillary rise or restriction of water flow downwards by an impervious layer; as the flow out of profile is based on excess water above FC $[\mathrm{D}(4)]$ or gravity unsaturated flow $\left(\mathrm{U}_{4 \rightarrow}\right)$. Thus this model cannot be used in the presence of shallow water tables or impeded drainage and cannot simulate soil salinity when derived from a shallow, saline water table.

\section{Salt Balance}

The salt balance was performed in conjunction with the water balance assuming complete mixing of water entering each layer with that already stored in that layer. The electrical conductivity of water (EC) was used as an indicator of salinity, assuming implicitly that there was a unique relationship between EC and total dissolved solids (TDS) in these dilute solutions and that the EC behaves like a non-reactive solute. Salinity of the input waters [irrigation water $\left(\mathrm{EC}_{\mathrm{w}}\right)$ and precipitation $\left.\left(\mathrm{EC}_{\mathrm{p}}\right)\right]$ must be known even though salt inputs are low. The mass of salts in layer $\mathrm{k}[\mathrm{Z}(\mathrm{k})]$ is estimated from the product $\mathrm{EC}_{\mathrm{sw}}(\mathrm{k}) \cdot \mathrm{W}(\mathrm{k})$, where $\mathrm{EC}_{\mathrm{sw}}$ is the electrical conductivity of the soil water in that layer. The mass of salts in layer $\mathrm{k}$ 
in day $1(\mathrm{t}+1)$ results from the salinity in day 0 (or $\mathrm{t}$ ) and the salt fluxes in day 1 that are added sequentially:

1. The salts in I and $P$ are added to the salt mass in layer 1 to obtain $Z^{\mathrm{a}}(1)_{1}$. Salts leaving layer 1 (D) are inputs to the layer 2 and so on such that $\left(Z^{\mathrm{a}}(\mathrm{x})_{1}, \mathrm{x}=2-3-4\right)$ :

$$
\begin{array}{ll}
\mathrm{Z}^{\mathrm{a}}(1)_{1}=\mathrm{Z}(1)_{0}+\mathrm{EC}_{\mathrm{w}} \cdot \mathrm{I}(1)_{1}+\mathrm{EC}_{\mathrm{p}} \cdot \mathrm{P}(1)_{1} & \text { for layer } 1 \text { or } \\
\mathrm{Z}^{\mathrm{a}}(\mathrm{x})_{1}=\mathrm{Z}(\mathrm{x})_{0}+1+\mathrm{EC}_{\mathrm{sw}}(1)_{0} \cdot \mathrm{D}(1)_{1} & \text { for layers } 2,3 \text { and } 4
\end{array}
$$

This results in a soil water concentration of

$$
\begin{array}{ll}
\mathrm{EC}_{\mathrm{sw}}^{\mathrm{a}}(1)_{1}=\mathrm{Z}^{\mathrm{a}}(1)_{1} /\left[\mathrm{W}(1)_{0}+\mathrm{I}_{1}+\mathrm{P}_{1}\right] & \text { in layer } 1 \text { or } \\
\mathrm{EC}^{\mathrm{a}}{ }_{\mathrm{sw}}(\mathrm{x})_{1}=\mathrm{Z}^{\mathrm{a}}(\mathrm{x})_{1} /\left[\mathrm{W}(\mathrm{x})_{0}+\mathrm{D}(\mathrm{x}-1)_{1}\right] & \text { in layers } 2,3 \text { and } 4
\end{array}
$$

2. The drainage from any layer $(y=1-2-3-4)$ takes place with concentration $\mathrm{EC}^{\mathrm{a}}{ }_{\mathrm{sw}}$ so that the new mass of salts in layer " $y$ " is:

$$
\mathrm{Z}^{\mathrm{b}}(\mathrm{y})_{1}=\mathrm{Z}^{\mathrm{a}}(\mathrm{y})_{1}-\mathrm{EC}_{\mathrm{sw}}^{\mathrm{a}}(\mathrm{y})_{1} \cdot \mathrm{D}(\mathrm{y})_{1}
$$

and the new soil water concentration is

$$
\begin{array}{ll}
\mathrm{EC}^{\mathrm{b}}{ }_{\mathrm{sw}}(1)_{1}=\mathrm{Z}^{\mathrm{b}}(1)_{1} /\left[\mathrm{W}(1)_{\mathrm{t}}+\mathrm{I}_{1}+\mathrm{P}_{1}-\mathrm{D}(1)_{1}\right] & \text { for layer } 1 \text { and } \\
\mathrm{EC}^{\mathrm{b}}{ }_{\mathrm{sw}}(\mathrm{x})_{1}=\mathrm{Z}^{\mathrm{b}}(\mathrm{x})_{1} /\left[\mathrm{W}(\mathrm{x})_{\mathrm{t}}+\mathrm{D}(\mathrm{x}-1)_{1}-\mathrm{D}(\mathrm{x})_{1}\right] & \text { for layers } \mathrm{x}=2-3-4 . .
\end{array}
$$

3. The soil water at this stage is evapo-concentrated by the crop water uptake $\left(\mathrm{ET}_{\mathrm{r}}\right)$ :

$$
\begin{aligned}
& \mathrm{EC}^{\mathrm{c}}{ }_{\mathrm{sw}}(1)_{1}=\mathrm{Z}^{\mathrm{b}}(1)_{1} /\left[\mathrm{W}(1)_{\mathrm{t}}+\mathrm{I}_{1}+\mathrm{P}_{1}-\mathrm{D}(1)_{1}-\mathrm{ET}_{\mathrm{r}}(1)_{1}\right] \text { for layer } 1 \\
& \mathrm{EC}^{\mathrm{c}}{ }_{\mathrm{sw}}(\mathrm{x})_{1}=\mathrm{Z}^{\mathrm{b}}(\mathrm{x})_{1} /\left[\mathrm{W}(\mathrm{x})_{\mathrm{t}}+\mathrm{D}(\mathrm{x}-1)_{1}-\mathrm{D}(\mathrm{x})_{1}-\mathrm{ET}_{\mathrm{r}}(\mathrm{x})_{1}\right] \text { for layers } 2,3 \text { and } 4 \text { [Eq. 13] }
\end{aligned}
$$

4. The mass of salts in the slow flow $U$ are then added/removed to obtain the final mass of salts in the layer $\left[\mathrm{Z}(\mathrm{k})_{1}\right]$ :

$$
\begin{aligned}
& \mathrm{Z}(1)_{1}=\mathrm{Z}^{\mathrm{b}}(1)_{1}-\left(\mathrm{U}_{1-2}\right)_{1} \cdot \mathrm{EC}_{\mathrm{sw}}^{\mathrm{c}}(2)_{1} \text { if } \mathrm{U}_{1-2}<0 \quad \text { or } \\
& \mathrm{Z}(1)_{1}=\mathrm{Z}^{\mathrm{b}}(1)_{1}-\left(\mathrm{U}_{1-2}\right)_{1} \cdot \mathrm{EC}_{\mathrm{sw}}^{\mathrm{c}}(1)_{1} \text { if } \mathrm{U}_{1-2}>0 \quad \text { for layer } 1 \text {; } \\
& \mathrm{Z}(2)_{1}=\mathrm{Z}^{\mathrm{b}}(2)_{1}+\left(\mathrm{U}_{1-2}\right)_{1} \cdot \mathrm{EC}^{\mathrm{c}}{ }_{\mathrm{sw}}(2)_{1}-\left(\mathrm{U}_{2-3}\right)_{1} \cdot \mathrm{EC}^{\mathrm{c}}{ }_{\mathrm{sw}}(3)_{1} \quad \text { if } \mathrm{U}_{1-2}<0 \text { and } \mathrm{U}_{2-3}<0 \text { or } \\
& \mathrm{Z}(2)_{1}=\mathrm{Z}^{\mathrm{b}}(2)_{1}+\left(\mathrm{U}_{1-2}\right)_{1} \cdot \mathrm{EC}_{\mathrm{sw}}^{\mathrm{c}}(1)_{1}-\left(\mathrm{U}_{2-3}\right)_{1} \cdot \mathrm{EC}_{\mathrm{sw}}^{\mathrm{c}}(3)_{1} \quad \text { if } \mathrm{U}_{1-2}>0 \text { and } \mathrm{U}_{2-3}<0 \text { or } \\
& \mathrm{Z}(2)_{1}=\mathrm{Z}^{\mathrm{b}}(2)_{1}+\left(\mathrm{U}_{1-2}\right)_{1} \cdot \mathrm{EC}_{\mathrm{sw}}^{\mathrm{c}}(2)_{1}-\left(\mathrm{U}_{2-3}\right)_{1} \cdot \mathrm{EC}_{\mathrm{sw}}^{\mathrm{c}}(2)_{1} \quad \text { if } \mathrm{U}_{1-2}<0 \text { and } \mathrm{U}_{2-3}>0 \text { or } \\
& \mathrm{Z}(2)_{1}=\mathrm{Z}^{\mathrm{b}}(2)_{1}+\left(\mathrm{U}_{1-2}\right)_{1} \cdot \mathrm{EC}_{\mathrm{sw}}^{\mathrm{c}}(1)_{1}-\left(\mathrm{U}_{2-3}\right)_{1} \cdot \mathrm{EC}_{\mathrm{sw}}^{\mathrm{c}}(2)_{1} \quad \text { if } \mathrm{U}_{1-2}>0 \text { and } \mathrm{U}_{2-3}>0 \text { or }
\end{aligned}
$$

for layer 2 (exchange 1-2-3 by 2-3-4 for layer 3); and

$$
\begin{array}{ll}
\mathrm{Z}(4)_{1}=\mathrm{Z}^{\mathrm{b}}(4)_{1}+\left(\mathrm{U}_{3-4}\right)_{1} \cdot \mathrm{EC}_{\mathrm{sw}}^{\mathrm{c}}(3)_{1}+\mathrm{U}_{4 \rightarrow} \cdot \mathrm{EC}_{\mathrm{sw}}^{\mathrm{c}}(4) & \text { if } \mathrm{U}_{3-4}>0 \text { or } \\
\mathrm{Z}(4)_{1}=\mathrm{Z}^{\mathrm{b}}(4)_{1}+\left(\mathrm{U}_{3-4}\right)_{1} \cdot \mathrm{EC}_{\mathrm{sw}}^{\mathrm{c}}(4)_{1}+\mathrm{U}_{4 \rightarrow} \cdot \mathrm{EC}_{\mathrm{sw}}^{\mathrm{c}}(4) & \text { if } \mathrm{U}_{3-4}<0
\end{array}
$$

for layer 4 .

[Eq. 14] 
which allows for calculating the final soil water concentration in layer $\mathrm{k}$ :

$$
\mathrm{EC}_{\mathrm{sw}}(\mathrm{k})_{1}=\mathrm{Z}(\mathrm{k})_{1} / \mathrm{W}(\mathrm{k})_{1}
$$

Then, the EC of the saturation extract $\left[\mathrm{EC}_{\mathrm{e}}(\mathrm{k})_{\mathrm{t}}\right]$ of layer $k$ in day $t$ is calculated from the EC of the soil solution and the water content in the layer on that day $\left[\mathrm{EC}_{\mathrm{sw}}(\mathrm{k})_{\mathrm{t}}\right.$ and $\left.\mathrm{W}(\mathrm{k})_{\mathrm{t}}\right]$ as

$$
E C_{e}(k)_{t}=E C_{s w}(k)_{t} \quad \frac{W_{t}(k)}{S P(k)}
$$

where $\mathrm{SP}(\mathrm{k})$ is the water content of the saturated paste of that layer. The $\mathrm{SP}(\mathrm{k})$ is a sensitive parameter and should be assessed whenever possible; when not available, the traditional rule for most mineral soils is $\mathrm{SP}=2 \cdot \mathrm{FC}$.

The arithmetic mean $\left[\mathrm{EC}_{\mathrm{e}}\right]$ and the uptake weighted mean of the 4 layers $\left[\mathrm{EC}_{\mathrm{e}}(\mathrm{w})\right]$ of the daily $\mathrm{EC}_{\mathrm{e}}(\mathrm{k})$ were calculated for every day $t$ :

$$
\mathrm{EC}_{\mathrm{et}}=\frac{1}{4} \sum_{\mathrm{k}=1}^{4} \mathrm{EC}_{\mathrm{et}}(\mathrm{k}) ; \quad \mathrm{EC}_{\mathrm{e}}(\mathrm{w})_{\mathrm{t}}=\frac{\sum_{\mathrm{k}=1}^{4} \mathrm{ET}_{\mathrm{rt}}(\mathrm{k}) \cdot \mathrm{EC}_{\mathrm{et}}(\mathrm{k})}{\sum_{\mathrm{k}=1}^{4} \mathrm{ET}_{\mathrm{r}_{\mathrm{t}}}(\mathrm{k})}
$$

Generally crops respond to the mean salinity of the root zone over the entire growing season (Ayers and Westcot 1985). Therefore the daily values of $\mathrm{EC}_{\mathrm{e}}$ [and $\mathrm{EC}_{\mathrm{e}}(\mathrm{w})$ as well] were averaged over the entire growing season:

$$
E C_{e S}=\frac{\sum_{\text {Growing Season }} E C_{e_{t}}}{\text { Number of days in the growing season }}
$$

which gives the seasonal-average rootzone $\mathrm{EC}_{\mathrm{e}}\left(\mathrm{EC}_{\mathrm{eS}}\right)$. This value can be compared with the crop salt tolerance $\mathrm{EC}_{\mathrm{e}}$ values to determine the yield loss (if any) due to salinity. It is generally assumed that crops respond to the mean seasonal soil salinity but in reality crop salt tolerance changes with growth stage. Since salt-tolerance response functions in relation to changing growth stage are lacking, the model assumes that crops respond to the average rootzone salinity. The model can be used also to adjust the $\mathrm{EC}_{\mathrm{w}}$ that results in a seasonal average $\mathrm{EC}_{\mathrm{e}}$ low enough to prevent salinity induced yield losses for that crop, which is particularly attractive to policy makers.

The mean daily $\mathrm{EC}_{\mathrm{e}}$ was also averaged over the whole hydrologic year $\left(\mathrm{EC}_{\mathrm{eHY}}\right)$ and can be averaged over any other period of interest. The seasonal uptake weighted $\mathrm{EC}_{\mathrm{e}}\left[\mathrm{EC}_{\mathrm{e}}(\mathrm{w})\right]$ is better related to crop response in high frequency irrigation systems (drip irrigation) (Ayers and Westcot 1985).

\section{Model application}


The model was applied to eight irrigated corn scenarios resulting from the combination of two soils, two rainfall distribution records, and two irrigation methods (sprinkler and basin). These scenarios were intended to provide information about the resulting $\mathrm{EC}_{\mathrm{e}}$ during the growing season $\left(\mathrm{EC}_{\mathrm{eS}}\right.$, the main objective of this paper), and the hydrologic year $\left(\mathrm{EC}_{\mathrm{eHY}}\right)$ under a wide range of climatic, management and soil conditions.

The selected soils were the series Hesperia fine sandy loam moderately deep (Hst) and Capay soils flooded (Cc) (National Resources Conservation Service 1968), both uniform down to 75 cm deep (the selected rooting depth for corn; Hanson et al. 1996). These soils varied drastically in textural class. The Cc soil series are silty-loam soils with low permeability whereas the Hst series are sandy loam soils with a 30-fold higher $\mathrm{K}_{\mathrm{s}}$ (Table 1). The clay content ( $\mathrm{C}$ in weight fraction), $\mathrm{K}_{\mathrm{S}}$ and textural class were taken from the National Resources Conservation Service (NRCS) soil surveys of Yolo and Fresno counties. These soils were selected for their homogeneity (absence of textural or conductance discontinuities) and their different hydraulic properties $\left(\mathrm{K}_{\mathrm{S}}\right.$ and TAW). Soil properties required for model application (sand and silt content, wilting point, field capacity, porosity and saturated paste water content) inferred from the soil surveys are reported in Table 1.

Table 1 Soil properties considered for the soil water and salt balance: Sand (S), Clay (C) and Silt ( $\mathrm{Si}$ ) content, textural class, hydraulic conductivity $\left(\mathrm{K}_{\mathrm{s}}\right)$, water content of the saturated paste (SP), field capacity $\left(\mathrm{FC}, \mathrm{cm}^{3} / \mathrm{cm}^{3}\right.$ ), permanent wilting point (WP) and total available water (TAW)

\begin{tabular}{|c|c|c|c|c|c|c|c|c|c|c|}
\hline \multirow[b]{2}{*}{ Soil } & \multicolumn{3}{|c|}{ Weight fraction } & \multirow[b]{2}{*}{ Texture } & \multirow{2}{*}{$\begin{array}{c}\mathrm{K}_{\mathrm{s}} \\
\mathrm{cm} / \mathrm{d}\end{array}$} & \multirow[t]{2}{*}{ SP } & \multirow{2}{*}{$\begin{array}{c}\mathrm{FC} \\
\mathrm{cm}^{3} / \mathrm{cm}^{3}\end{array}$} & \multirow[t]{2}{*}{ WP } & \multicolumn{2}{|c|}{ TAW } \\
\hline & $\mathrm{S}$ & $\mathrm{C}$ & $\mathrm{Si}$ & & & & & & $\mathrm{cm}^{3} / \mathrm{cm}^{3}$ & $\mathrm{~mm}$ \\
\hline $\mathrm{Cc}$ & 0.075 & 0.475 & & & 7.9 & 0.52 & 0.364 & 0.2 & 0.141 & 105 \\
\hline Hst & .65 & 0.125 & 0.225 & S-L & 241.9 & 0.429 & 0.198 & 0.119 & 0.079 & 59.6 \\
\hline
\end{tabular}

To test the influence of rainfall distribution, two precipitation records (having similar annual rainfall averages but different distributions throughout the year) were selected: Davis CA (470 mm/yr; 1951 to 2006) and Almudévar, Spain (457 mm/yr; 1964 to 2006). The model was applied to all the available meteorological data (56 years in Davis and 43 years in Almudévar) (Fig. 1). The temperature (T) and $\mathrm{ET}_{\mathrm{c}}$ values were assumed to be the same for both locations (Davis data) in order to test models influence by rainfall distribution only. The meteorological records for Davis were taken from the National Climate Data Center (2004) and the data for Almudévar were facilitated by the Agencia Estatal de Meteorología of Spain. 


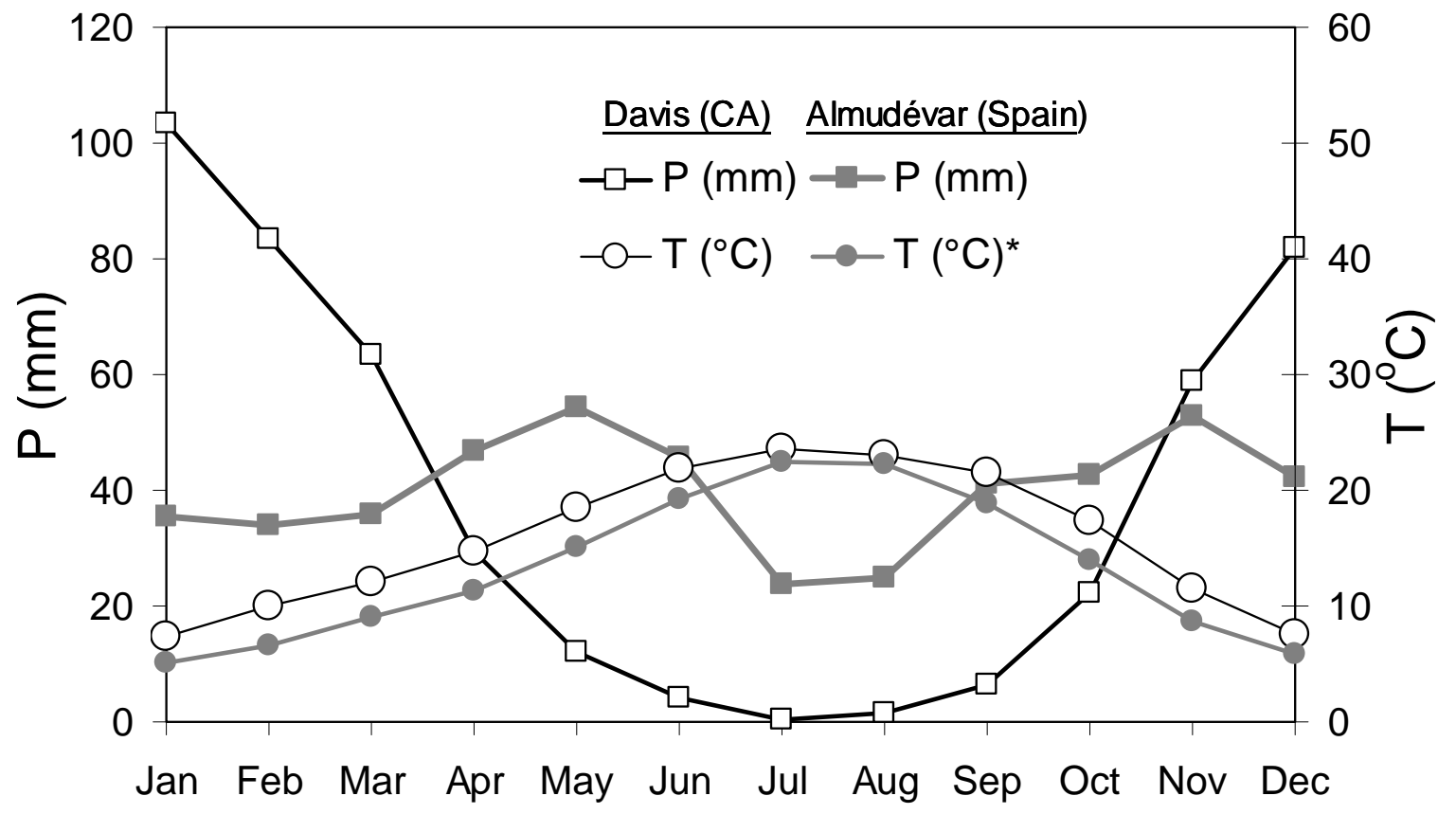

Fig. 1 Mean monthly rainfall $(\mathrm{P})$ and temperature $(\mathrm{T})$ in the stations of Davis and Almudévar (* $\mathrm{T}$ data from Almudévar were not used and are presented here only for comparison purposes)

In Davis, rainfall was concentrated in winter $(88 \%$ of rainfall took place from October to March), whereas in Almudévar rainfall was more uniformly distributed throughout the year (only 51\% from October to March). Total annual rainfall was almost the same in both locations but slightly more variable in Davis (ranging from $143 \mathrm{~mm}$ to $969 \mathrm{~mm}$, $\mathrm{CV}=33.6 \%$ ) than in Almudévar (from $228 \mathrm{~mm}$ to $819 \mathrm{~mm}, \mathrm{CV}=26.8 \%$ ).

Finally, two irrigation management scenarios were tested: In the Sprinkler method, the irrigation amounts were calculated based on 11-day (fine-textured soil; Cc) or 6-day (coarsetextured soil; Hst) $\mathrm{ET}_{\mathrm{c}}$ forecasts and the dates of irrigation were chosen when the crop reached stress $(\mathrm{W}<\mathrm{We})$. This is the case of a sprinkler irrigation system where the date of irrigation can be chosen freely and the amount adjusted to forecasted needs. The adjustment of the amounts to the $\mathrm{ET}_{\mathrm{c}}$ forecast and the choice of the irrigation dates based on $\mathrm{W}$ assumed that there was an adequate knowledge of soil properties and good management was practiced. The amount of water applied in each location was based only on predicted $\mathrm{ET}_{\mathrm{c}}$ and did not consider in-season precipitation or any leaching fraction. The leaching in each scenario stems from irrigation applications above the actual soil water deficit and from seasonal rainfall. This leaching occurs because applications are calculated based on $\mathrm{ET}_{\mathrm{c}}$ forecasts which are usually different from the actual soil water deficit. 
Under the Surface irrigation method, the number of irrigations along the season was fixed at 9 in both soils. Each irrigation event took place when the cumulative $\mathrm{ET}_{\mathrm{c}}$ reached a tenth of the seasonal $\mathrm{ET}_{\mathrm{c}}$ and the amount applied was always the same: 1/9 of the seasonal $\mathrm{ET}_{\mathrm{c}}$ (with 9 irrigations, the growing season is divided into 10 ET events; one before the first irrigation and one after the final irrigation). As it was assumed to be a rigid irrigation system, no differences were introduced in the Surface method between the two soil types. In both irrigation methods, no irrigation was allowed in the last 15 days of the growing season, to follow normal grower practices.

All the scenarios were tested with an irrigation water $\mathrm{EC}\left(\mathrm{EC}_{\mathrm{w}}\right)$ of $0.7 \mathrm{dS} / \mathrm{m}$ because under the classic FAO 29 steady-state approach a mean $\mathrm{EC}_{\mathrm{eS}}$ of $1.0 \mathrm{dS} / \mathrm{m}$ (a value considered nongrowth limiting even for the most salt-sensitive crops) results from using an irrigation water with an $\mathrm{EC}_{\mathrm{w}}=0.7 \mathrm{dS} / \mathrm{m}$ and leaching fraction (LF) between 0.15 to 0.20 . The $\mathrm{EC}$ of the precipitation water $\left(\mathrm{EC}_{\mathrm{p}}=0.007 \mathrm{dS} / \mathrm{m}\right)$ was averaged from data of the National Atmospheric Deposition Program (2005) for Davis.

The model was applied to both meteorological series assuming the same management practices for all years, selected from the typical corn cropping practices in Yolo County. The growing season was assumed to be from May $1^{\text {st }}$ to September $27^{\text {th }}$ (150 days: 30 for Stage 1, 40 for Stage 2, 50 for Stage 3, and 30 for Stage 4). The objective was not to actually simulate a 56 year continuous cropping of corn (43 for the Alm rainfall series), but to provide a multiple-year record of seasonal or annual $\mathrm{EC}_{\mathrm{e}}$ averages (and related parameters).

The hydrologic and management parameters calculated for each scenario were the precipitation $(\mathrm{P})$, the volume of drainage $[\mathrm{D}$, where $\mathrm{D}$ stands for both $\mathrm{D}$ and $\mathrm{U}$ down the fourth layer: $\left.\mathrm{D}=\mathrm{D}(4)+\mathrm{U}_{4 \rightarrow}\right]$, the leaching fraction $[\mathrm{LF}=\mathrm{D} /(\mathrm{I}+\mathrm{P})]$, and the mass of salts leached [estimated as Salt $(\mathrm{kg} / \mathrm{ha})=7 \cdot \mathrm{EC}_{\mathrm{d}}(\mathrm{dS} / \mathrm{m}) \cdot \mathrm{D}(\mathrm{mm})$; i.e. assuming a factor of

$700\left(\mathrm{mg} \cdot \mathrm{L}^{-1}\right) \cdot\left(\mathrm{dS} \cdot \mathrm{m}^{-1}\right)$ to convert EC into TDS, Rhoades et al. 1992] for both the whole year and the irrigation season; the volume of irrigation (I), the number of irrigations $(\mathrm{N})$, and the seasonal ET deficit $\left(1-\mathrm{ET}_{\mathrm{r}} / \mathrm{ET}_{\mathrm{c}}\right)$ that determines the yield loss due to water stress (Doorenbos and Kassam 1979).

\section{Results and discussion}

Water and salt balance

The results of the first-year simulation (1951) for the Davis rainfall series is presented under this section for illustration purposes of the models outputs. The simulated water contents in 
each layer are presented in Fig. 2 along with daily rainfall and irrigation for a sandy loam soil (Hst) in Davis using surface irrigation. The water content in the four layers stayed above WP and for most days below FC: only in days when $\mathrm{W}(\mathrm{k})>\mathrm{FC}(\mathrm{k})$ did drainage (D) take place from layer $\mathrm{k}$. On the other hand, the water movement term that depends upon soil water potentials (U) occurred with lower water contents and was responsible for the slow W decrease in layers 2, 3 and 4 during the non growing season, when these layers produced drainage (downward flow) and when water also moved towards the upper layer (upward flow) which contributed to the non seasonal $\mathrm{ET}_{\mathrm{r}}(1)$ (Fig. 3).

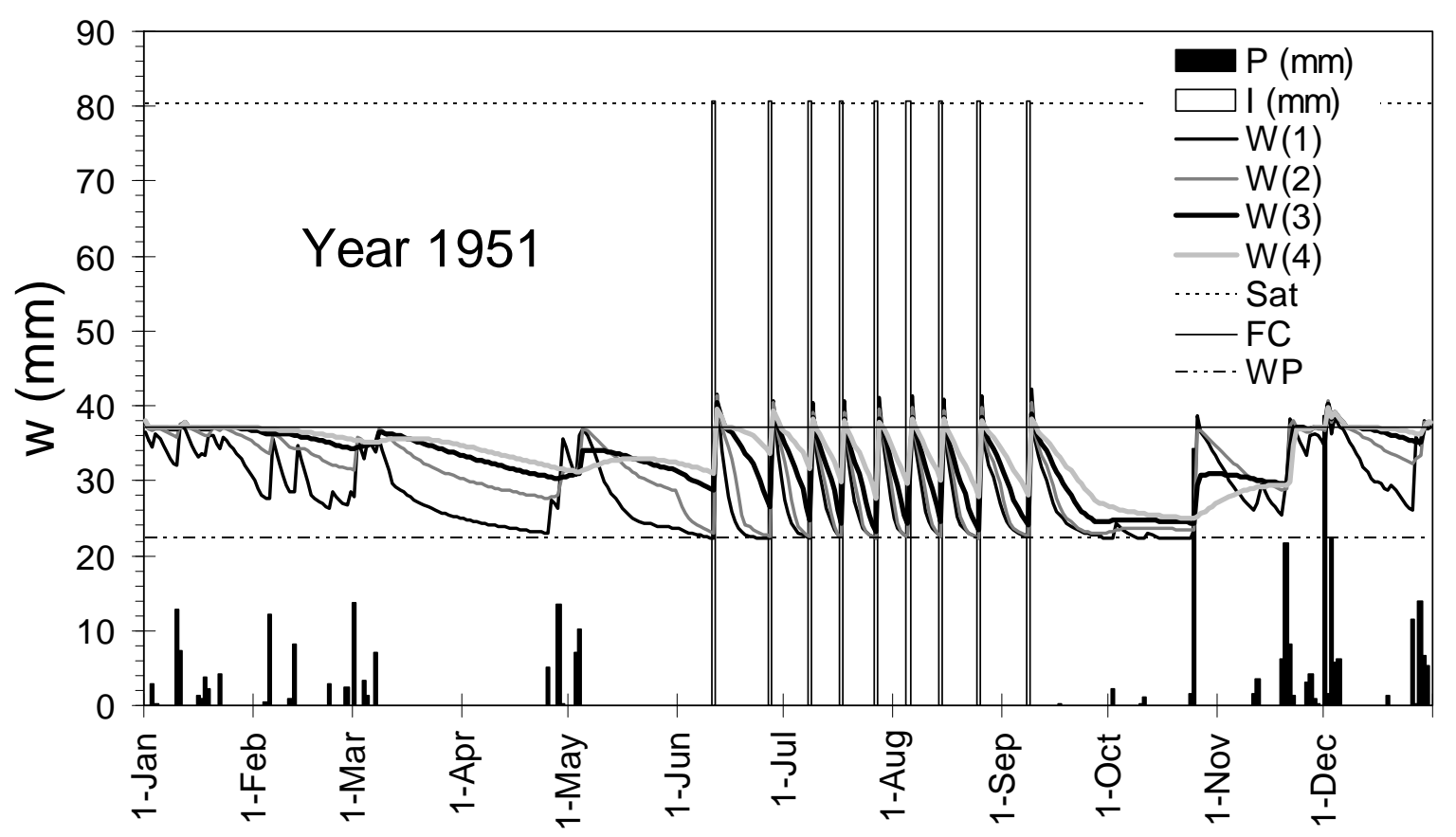

Fig. 2 Soil water content in the four soil layers $[\mathrm{W}(1)$ to $\mathrm{W}(4)]$, precipitation $(\mathrm{P})$ and irrigation (I) along the first-year (1951) simulation for a surface irrigated corn crop using the Davis rainfall series on soil Hst (sandy loam). The water contents at saturation (Sat), field capacity (FC) and wilting point (WP) of the layers are also shown

In some years, particularly for low TAW soils and long interval irrigations, the calculated ET $\left(\mathrm{ET}_{\mathrm{r}}\right.$ ) was clearly lower than $\mathrm{ET}_{\mathrm{c}}$ showing that the crop experienced water stress (Fig. 3). The ET deficit during the growing season $\left(\mathrm{ET}_{\mathrm{def}}=1-\mathrm{ET}_{\mathrm{r}} / \mathrm{ET}_{\mathrm{c}}\right.$, $)$ is related to the yield loss induced by water stress (Doorenbos and Kassam 1979). Figure 3 also indicates that $\mathrm{ET}_{\mathrm{r}}$ took place only from the upper soil layer during the non-growing season and the initial stage of crop growth.

The mean daily $\mathrm{EC}_{\mathrm{e}}$ for the same soil selected in Figs. 2 and 3 under surface irrigation is illustrated in Figure 4. Each irrigation event adds some salts that are leached as drainage following the irrigation, causing the spikes during the growing season. The reduction in 
salinity in the winter and early spring is due to rainfall leaching (Fig. 2). During the nongrowing season and the first stage of crop development, the $\mathrm{EC}_{\mathrm{e}}(1)$ is taken as $\mathrm{EC}_{\mathrm{e}}$.

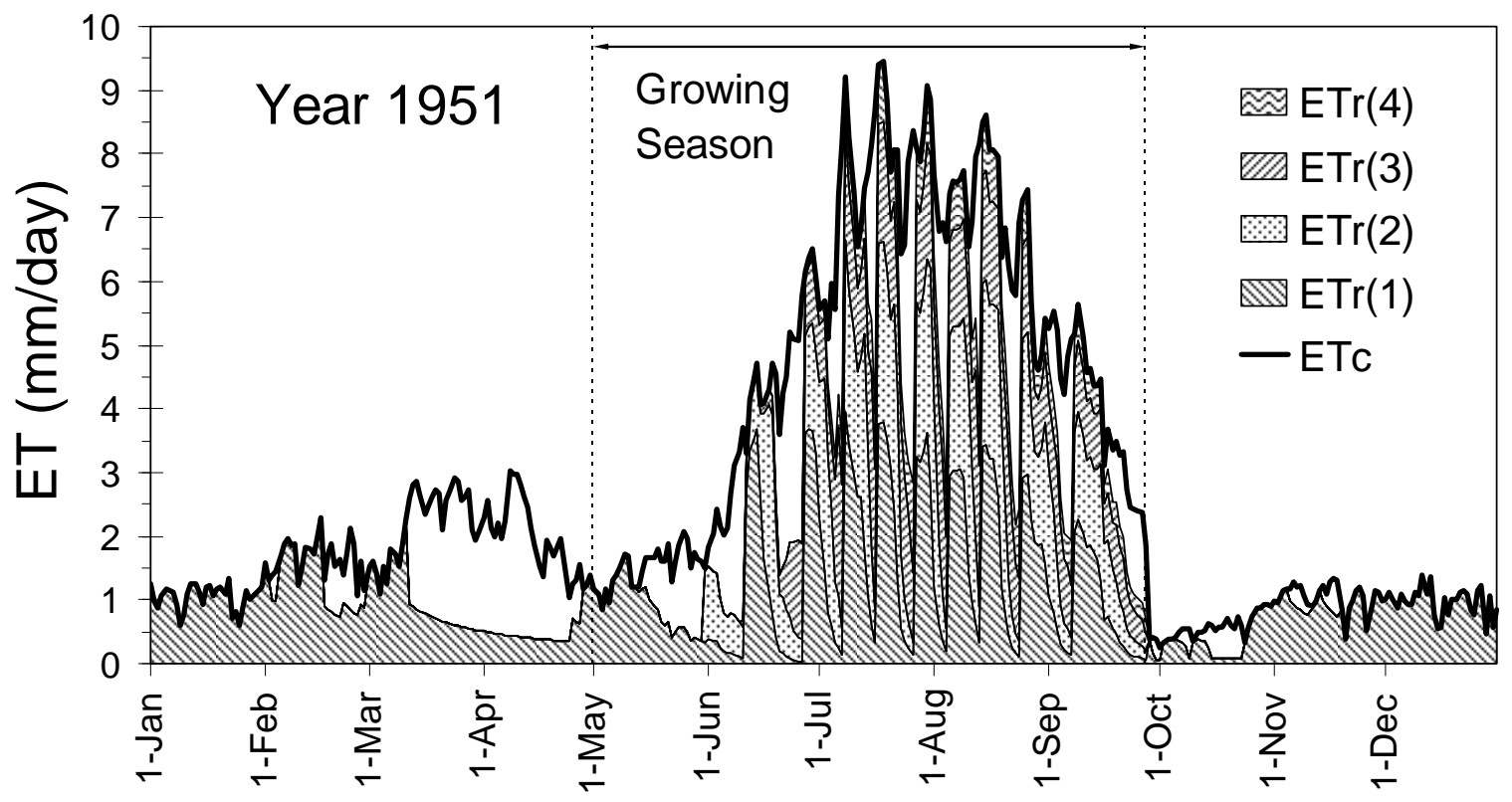

Fig. 3 Simulated ET from the each soil layer $\left[\operatorname{ET}_{\mathrm{r}}(1), \operatorname{ET}_{\mathrm{r}}(2), \operatorname{ET}_{\mathrm{r}}(3)\right.$, and $\left.\operatorname{ET}_{\mathrm{r}}(4)\right]$ and maximum achievable crop ET of corn $\left(\mathrm{ET}_{\mathrm{c}}\right)$ along the first year of simulation for the Davis rainfall series with surface irrigation on soil Hst (sandy loam). The fraction of unshaded area below the $\mathrm{ET}_{\mathrm{c}}$ curve during the growing season represents the ET deficit

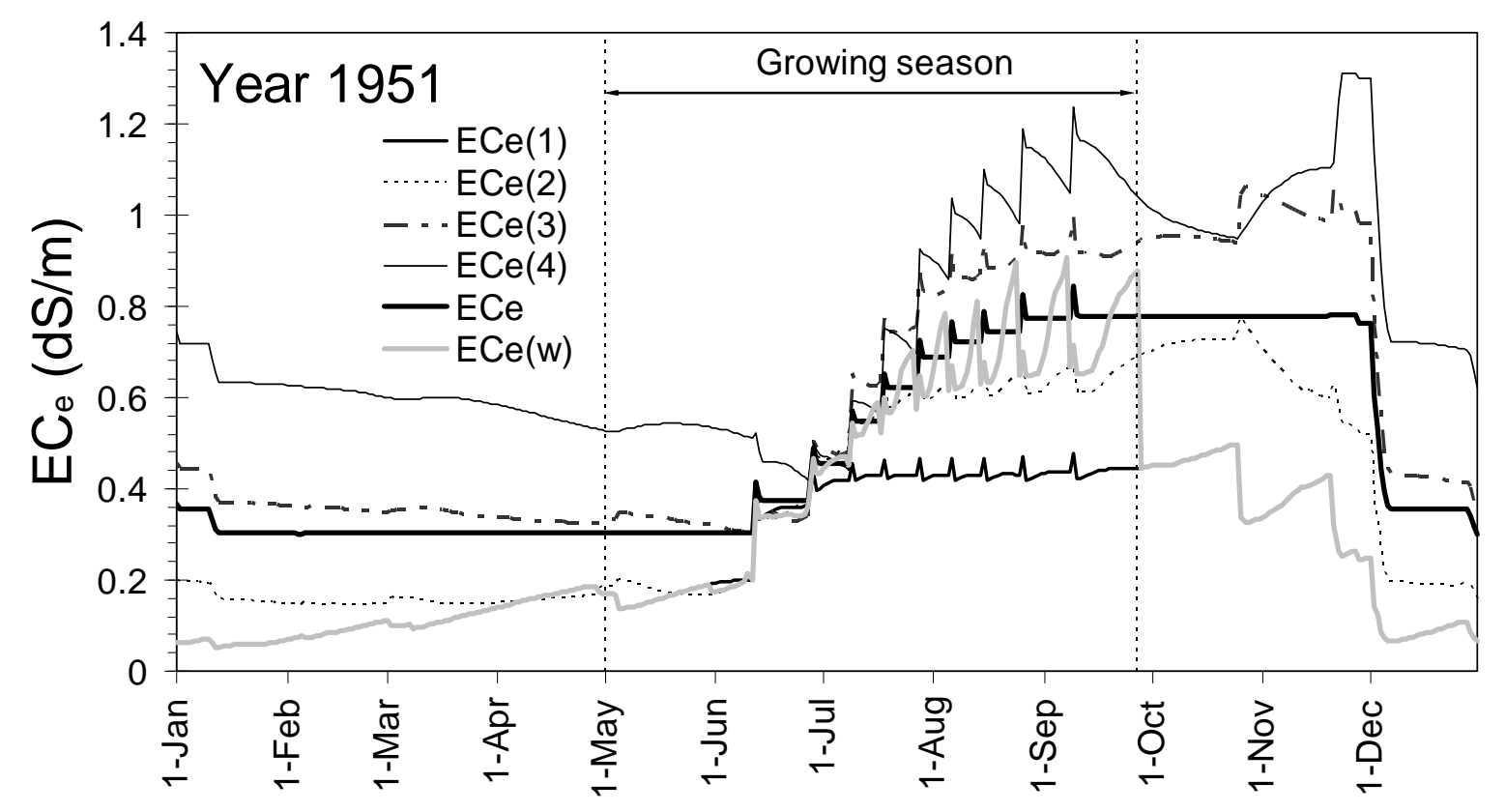

Fig. 4 Simulated daily electrical conductivity of the saturated paste extract of each soil layer $\left[\mathrm{EC}_{\mathrm{e}}(1)\right.$ to $\left.\mathrm{EC}_{\mathrm{e}}(4)\right]$, mean $\mathrm{EC}_{\mathrm{e}}$ of the soil profile $\left(\mathrm{EC}_{\mathrm{e}}\right)$ and root water uptake weighted mean $\mathrm{EC}_{\mathrm{e}}$ of the 4 layers $\left[\mathrm{EC}_{\mathrm{e}}(\mathrm{w})\right]$ along the first year of simulation (1951) for a surface irrigated corn crop using the Davis rainfall series on soil Hst 


\section{Comparison of the different scenarios}

\section{Irrigation method and soil textual class}

Both the method of irrigation and soil textural class had a strong influence on the model results. The volume of irrigation applied (I) was slightly higher for the surface irrigation method $(712 \mathrm{~mm})$ than the sprinkler method $(626 \mathrm{~mm})$ and within the sprinkler method, slightly higher for the Davis rainfall series $(671 \mathrm{~mm})$ than the Almudévar rainfall series (568 $\mathrm{mm}$ ) due to the higher summer precipitation of Almudévar (Table 2). The differences in I between soils within each rainfall series in the sprinkler method were much smaller; but the number of irrigations required in the coarse-textured soil (Hst; lowest TAW) doubled the number in the fine-textured soil, $\mathrm{Cc}$ (in the surface method, both I and $\mathrm{N}$ were defined equal).

Sprinkler irrigation always provided enough water to practically avoid crop stress (ET deficit $<2 \%$ in all scenarios). Surface irrigation on the fine-textured soil provided similar results (ET deficit $<3 \%$ ); but on course-textured soil, the long irrigation intervals combined with the low TAW led to crop water stress: $12 \%$ for the Almudévar rain series and 20\% for the Davis series, which presented lower summer precipitation (Table 2).

Table 2 Indicators of the irrigation performance under the different irrigation methods (Sprinkler or Surface) tested under different rainfall series [Davis or Almudévar (Alm)] and different soil classes (Fine textured Capay or Coarse textured Hesperia): volume of irrigation (I) and number $(\mathrm{N})$ of irrigations applied; deficit $\mathrm{ET}\left(\mathrm{ET}_{\mathrm{def}}=1-\mathrm{ET}_{\mathrm{r}} / \mathrm{ET}_{\mathrm{c}}\right)$ and volume of drainage (D), leaching fraction (LF), mass of salts leached (Salt) and mean concentration of the leachate for both the growing season (S) and the whole hydrologic year (HY)

\begin{tabular}{|c|c|c|c|c|c|c|c|c|c|c|c|c|c|}
\hline \multirow[b]{2}{*}{ Method } & \multirow[b]{2}{*}{ Rain } & \multirow[b]{2}{*}{ Soil } & \multirow[t]{2}{*}{$\begin{array}{c}\mathrm{I} \\
\mathrm{mm}\end{array}$} & \multirow[t]{2}{*}{$\mathrm{N}$} & \multirow[t]{2}{*}{$\begin{array}{c}\mathrm{ET}_{\text {def }} \\
\%\end{array}$} & \multicolumn{2}{|c|}{$\begin{array}{c}\mathrm{D} \\
\mathrm{Mm}\end{array}$} & \multicolumn{2}{|c|}{$\mathrm{LF}$} & \multicolumn{2}{|c|}{$\begin{array}{c}\text { Salt } \\
(\mathrm{kg} / \mathrm{ha})\end{array}$} & \multicolumn{2}{|c|}{$\begin{array}{c}\text { Leachate } \\
(\mathrm{mg} / \mathrm{L})\end{array}$} \\
\hline & & & & & & $\mathrm{S}$ & HY & $\mathrm{S}$ & HY & $\mathrm{S}$ & HY & $\mathrm{S}$ & HY \\
\hline \multirow[t]{6}{*}{ Sprinkler } & Davis & Fine & 667 & 11 & 1 & 38 & 257 & 0.06 & 0.21 & 456 & 3310 & 1189 & 1288 \\
\hline & & Coarse & 675 & 22 & 2 & 26 & 259 & 0.04 & 0.21 & 371 & 3336 & 1431 & 1290 \\
\hline & Total & & 671 & 16 & 2 & 32 & 258 & 0.05 & 0.21 & 414 & 3323 & 1286 & 1289 \\
\hline & Alm & Fine & 564 & 8 & 1 & 71 & 131 & 0.09 & 0.12 & 1375 & 2767 & 1932 & 2108 \\
\hline & & Coarse & 572 & 17 & 2 & 70 & 138 & 0.09 & 0.13 & 1255 & 2835 & 1800 & 2052 \\
\hline & Total & $\operatorname{lm}$ & 568 & 13 & 1 & 70 & 135 & 0.09 & 0.13 & 1315 & 2801 & 1867 & 2079 \\
\hline Total Spr & & & 626 & 15 & 2 & 49 & 204 & 0.07 & 0.17 & 805 & 3097 & 1650 & 1515 \\
\hline \multirow[t]{6}{*}{ Surface } & Davis & Fine & 713 & 9 & 3 & 76 & 305 & 0.10 & 0.24 & 950 & 3531 & 1252 & 1157 \\
\hline & & Coarse & 713 & 9 & 20 & 191 & 424 & 0.26 & 0.35 & 2062 & 3513 & 1079 & 828 \\
\hline & Total & avis & 713 & 9 & 12 & 133 & 365 & 0.18 & 0.30 & 1506 & 3522 & 1129 & 966 \\
\hline & Alm & Fine & 712 & 9 & 1 & 203 & 273 & 0.22 & 0.23 & 2515 & 3525 & 1240 & 1293 \\
\hline & & Coarse & 712 & 9 & 12 & 281 & 351 & 0.31 & 0.30 & 2828 & 3533 & 1006 & 1005 \\
\hline & Total & & 712 & 9 & 6 & 242 & 312 & 0.27 & 0.26 & 2672 & 3529 & 1104 & 1131 \\
\hline Total Surf & & & 712 & 9 & 9 & 181 & 342 & 0.22 & 0.28 & 2012 & 3525 & 1114 & 1031 \\
\hline Total & & & 669 & 12 & 5 & 115 & 273 & .14 & 0.23 & 1409 & 3311 & 1228 & 1212 \\
\hline
\end{tabular}


Drainage and LF were clearly higher for the surface method (181 mm and 0.22) than the sprinkler irrigation method (49 $\mathrm{mm}$ and 0.07 ) during the growing season, but the difference was tampered for the hydrologic year: $342 \mathrm{~mm} \mathrm{(0.28)}$ for the surface method and $204 \mathrm{~mm}$ (0.17) for the sprinkler method (Table 2). The Almudévar rain series produced seasonal D about twice as high as the Davis series in both methods $(70 \mathrm{~mm}$ vs. $32 \mathrm{~mm}$ in the sprinkler method and $242 \mathrm{~mm}$ vs. $133 \mathrm{~mm}$ in the surface method) due to its higher seasonal precipitation; but the hydrologic year D was higher for the Davis series $(258 \mathrm{~mm}$ vs. $135 \mathrm{~mm}$ in the sprinkler method and $365 \mathrm{~mm}$ vs. $312 \mathrm{~mm}$ in the surface method), showing that drainage was more concentrated during the winter for the Davis series (Table 2). In fact, the ratio of seasonal D to yearly D in Davis was 1 to 8 in the sprinker method (only 1 to 1.9 for the Alm series) and 1 to 2.7 in the surface method (only 1 to 1.3 for the Alm series) (Table 2). The seasonal drainage from the fine-textured soil $(\mathrm{Cc})$ with the Davis rainfall series and surface method $(76 \mathrm{~mm})$ was much lower than that from the coarse-textured soil $(191 \mathrm{~mm})$, or from both soils within the Almudévar rainfall series (mean $242 \mathrm{~mm}$ ). Between soils, there were no apparent differences in seasonal or annual D in the sprinkler; but in the surface, D was much higher from fine-textured soil than from the same soil from the Alm series (281 mm vs. $203 \mathrm{~mm}$ ) and especially for the Davis series (191 mm vs. $76 \mathrm{~mm}$ ).

Generally, the leaching fractions presented a very similar behavior (Table 2): higher LF in the season for the Alm series than the Davis series (0.09 vs. 0.05 in sprinkle irrigation and 0.27 vs. 0.18 under surface irrigation and higher LF during the year for the Davis series than for the Alm series ( 0.21 vs. 0.13 in the case of sprinkler irrigation and 0.30 vs. 0.26 for surface irrigation). But the Almudévar rain series in surface irrigation resulted in the same LF in the season (mean 0.27) than in the whole year (mean 0.26) for both soils. Under surface irrigation, the LF was higher for the coarse-textured soil than soil $\mathrm{Cc}$ (during the season and the hydrologic year) but there were no differences between soils for the sprinkler method.

The mean seasonal LF for the 8 scenarios ranged from 0.04 to $0.13(0.12$ to 0.35 for the annual LF), but the individual LF obtained in the simulated series ranged from 0.03 to 0.40 for the season (from 0.02 to 0.53 for the year). Furthermore, this variability took place even though the irrigation volume (I) was defined, in both methods, to provide approximately the seasonal $\mathrm{ET}_{\mathrm{c}}$ in each season; showing the power of the capacity-based model to account for irrigation inefficiency (i.e. the same 'I' can give rise to many different LF's) and the influence of the irrigation methods, soil type and, especially, of the random distribution of rainfall on the resulting $\mathrm{LF}$. 
The mass of salts leached during the season or the hydrologic year varied in the same fashion as $\mathrm{D}$, though the actual masses were also influenced by the concentration of the drainage water (Table 2). The mass of salts leached was higher in the surface method $(2012 \mathrm{~kg} / \mathrm{ha})$ than with the sprinkler method $(805 \mathrm{~kg} / \mathrm{ha})$ during the season and to a lesser extent during the hydrologic year (3525 kg/ha vs. $3097 \mathrm{~kg} / \mathrm{ha})$. There were no apparent differences in the annual masses of the soils or rain series using the surface method (mean $3525 \mathrm{~kg} / \mathrm{ha}$ ) whereas in the sprinkler method, the mass was higher for the Davis series $(3323 \mathrm{~kg} / \mathrm{ha})$ than for the Alm series $(2801 \mathrm{~kg} / \mathrm{ha})$ and very similar for both soils within each rain series.

The concentration of salts in the leachate during the season was higher for the Alm series $(1867 \mathrm{mg} / \mathrm{L})$ than the Davis $(1286 \mathrm{mg} / \mathrm{L})$ series in using the sprinkler method and similar when using the surface method (mean $1114 \mathrm{mg} / \mathrm{L}$ ) (Table 2). For the hydrologic year, these differences increased. For all the cases and soils, the Davis rainfall series (winter concentrated) gave rise to higher D along the hydrologic year with lower concentration than the Almudévar series; and it was this higher D that led to a higher mass of salts exported. But during the growing season, both the mass of salts and $\mathrm{D}$ were higher for the Almudévar series than the Davis series in all soils and cases.

\section{Rainfall distribution}

The variability in the results (in the irrigation characteristics of the previous section and the resulting mean $\mathrm{EC}_{\mathrm{eS}}$ in the following section) within each scenario is due to the yearly differences in meteorological properties (mainly rainfall distribution but also, to a lesser extent, temperatures and ET) within each rainfall series. Each rainfall series utilized (Davis and Almudévar) resulted in a time series of $\mathrm{EC}_{\mathrm{eS}}$ for each combination of irrigation method and soil type, which are different in their mean values (differences between scenarios) and also in their distribution (Fig. 5).

For the Davis rainfall series the differences between sprinkler and surface irrigation were very low for the fine-textured soil (higher TAW) indicating that the leaching achieved by both methods of irrigation was quite similar and very clear for coarse-textured soil (lower TAW), showing that the leaching caused by the surface irrigation was much higher in the surface irrigation scenario [Fig. 5(a)]. 

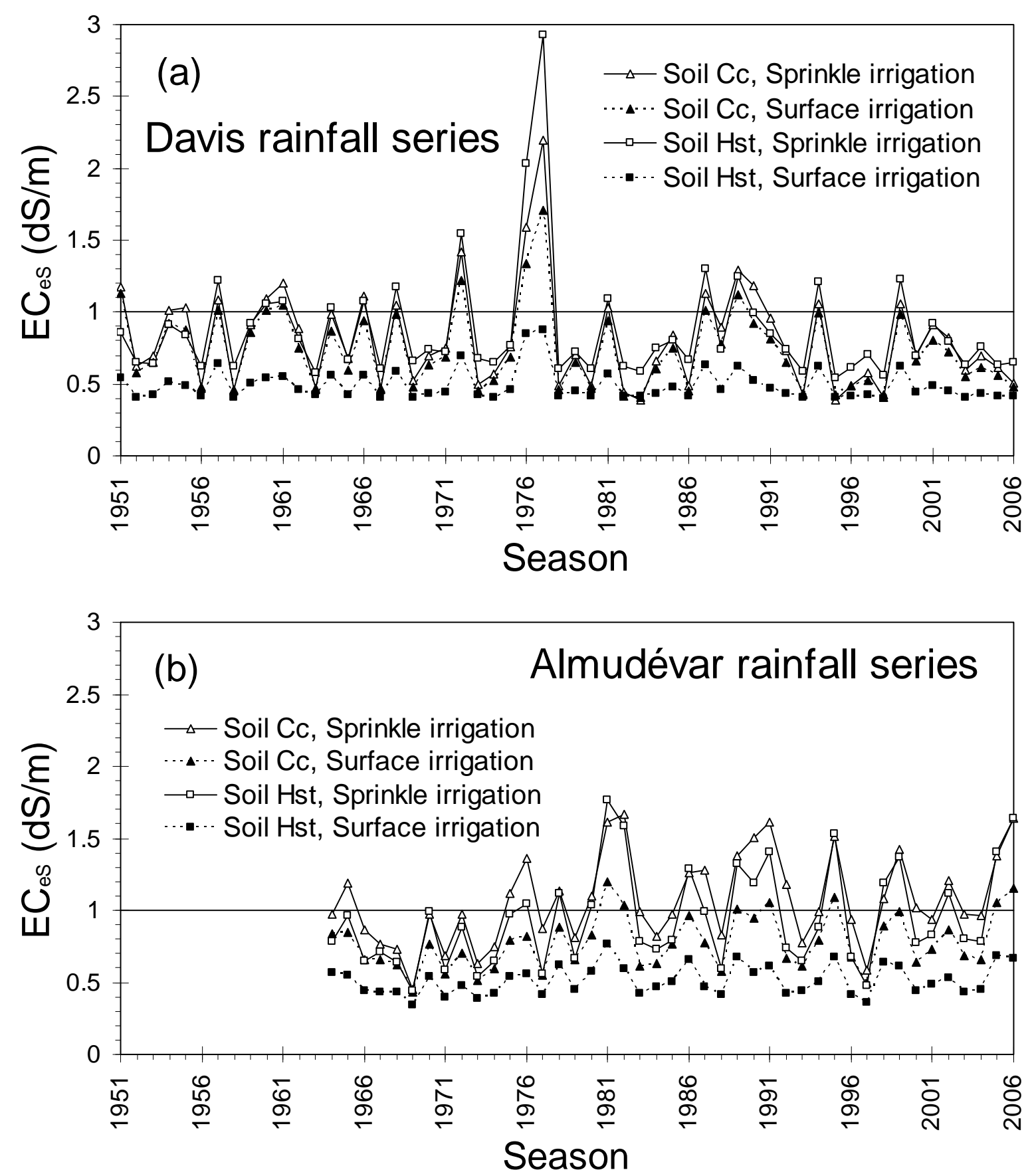

Fig. 5 Mean electrical conductivity of the saturated paste extract during the growing season $\left(\mathrm{EC}_{\mathrm{eS}}\right)$ for the simulated years in the 8 scenarios considered. The $\mathrm{EC}_{\mathrm{eS}}=1 \mathrm{dS} / \mathrm{m}$ line is presented for comparison purposes

In Davis, the $\mathrm{EC}_{\mathrm{eS}}$ on coarse-textured soils that were surface irrigated were clearly lower than those from the other three method-soil combinations and the behavior of both soils under the sprinkler method were quite similar [Fig. 5(a)]. For the Almudévar rain series, the differences between the two soils for the sprinkler method, and especially between both irrigation methods on coarse-textured soil, were a little more apparent; while the surface method for the coarser soil was again clearly lower than the others [Fig. 5(b)]. 


\section{Summary Analysis of the EC $\underline{\text { es. for the different scenarios }}$}

The records of yearly means of $\mathrm{EC}_{\mathrm{e}}$ along the growing season $\left(\mathrm{EC}_{\mathrm{eS}}\right)$ were taken as samples defining the behavior of soil salinity under the different scenarios. The differences in $\mathrm{EC}_{\mathrm{eS}}$ between scenarios and the relationship between $\mathrm{EC}_{\mathrm{es}}$ and other management (leaching fractions) or hydrologic parameters (rainfall, water content or initial soil water salinity) are presented.

The mean seasonal $\mathrm{EC}_{\mathrm{e}}\left(\mathrm{EC}_{\mathrm{eS}}\right)$ for all the cases (396) was $0.77 \mathrm{dS} / \mathrm{m}$, indicating that an irrigation water salinity with an $\mathrm{EC}_{\mathrm{w}}$ of $0.7 \mathrm{dS} / \mathrm{m}$ results in a $23 \%$ lower soil salinity that what is predicted to occur using the steady-state FAO 29 approach (i.e. $1.0 \mathrm{dS} / \mathrm{m}$ ). These seasonal $\mathrm{EC}_{\mathrm{e}}$ however were widely scattered (from $0.34 \mathrm{dS} / \mathrm{m}$ to $2.93 \mathrm{dS} / \mathrm{m}$ ) and depended strongly on the 3 factors defining the scenarios [Soil textual class; Rainfall distribution; Davis or Almudévar; and irrigation method (sprinkler or surface) as well as weather variables.

The analysis of variance for the variable $\mathrm{EC}_{\mathrm{eS}}$ on the factors Soil, Rain and Method showed that all the single factors were significant $(\mathrm{P}<0.001)$ as well as the interactions Soil-Method and Rain-Method $(\mathrm{P}<0.05$; although the significance of the interaction Soil-Method was introduced by the different definition of the irrigation scheme for the two soils using sprinkler irrigation). The interaction Rain-Method followed the fact that the difference between sprinkler and surface irrigation was higher for the Almudévar rainfall series than for the Davis series (Table 3).

The soil salinity along the growing season was always lower for the Davis $(0.73 \mathrm{dS} / \mathrm{m})$ rainfall series than the Almudévar $(0.82 \mathrm{dS} / \mathrm{m})$ series and for the surface irrigation method $(0.63 \mathrm{dS} / \mathrm{m})$ as compared to sprinkler irrigation $(0.91 \mathrm{dS} / \mathrm{m})$ (Table 3). Also, $\mathrm{EC}_{\mathrm{eS}}$ was lower for the coarse-textured soil (Hst; S-L) than for fine-textured soil (Cc; Si-C) except for sprinkler irrigation on the Davis rainfall series (Table 3): in surface irrigation the irrigation intervals are equal for both soil types despite their different TAW leading to a much higher leaching (Table 3), whereas the adjustment of the irrigation dose to the 6-day forecast in coarse-textured soil for sprinkler irrigation led to reduced leaching and to an $\mathrm{EC}_{\mathrm{eS}}$ similar (slightly higher but not significantly different: $\mathrm{P}>0.05$ ). Also, the driest years in the Davis rainfall series led to higher $\mathrm{EC}_{\mathrm{eS}}$ in the coarse-textured soil than in the fine-textured soil $\mathrm{Cc}$ (Fig. 5). 
Table 3 Means for all the simulations performed of the seasonal $\mathrm{EC}_{\mathrm{e}}\left(\mathrm{EC}_{\mathrm{eS}}\right)$ and the leaching fraction of the hydrologic year $\left(\mathrm{LF}_{\mathrm{HY}}\right)$ by irrigation method: Sprinkle or Surface; soil type: Fine or Coarse textured; and rainfall series: Davis or Almudévar (Alm)

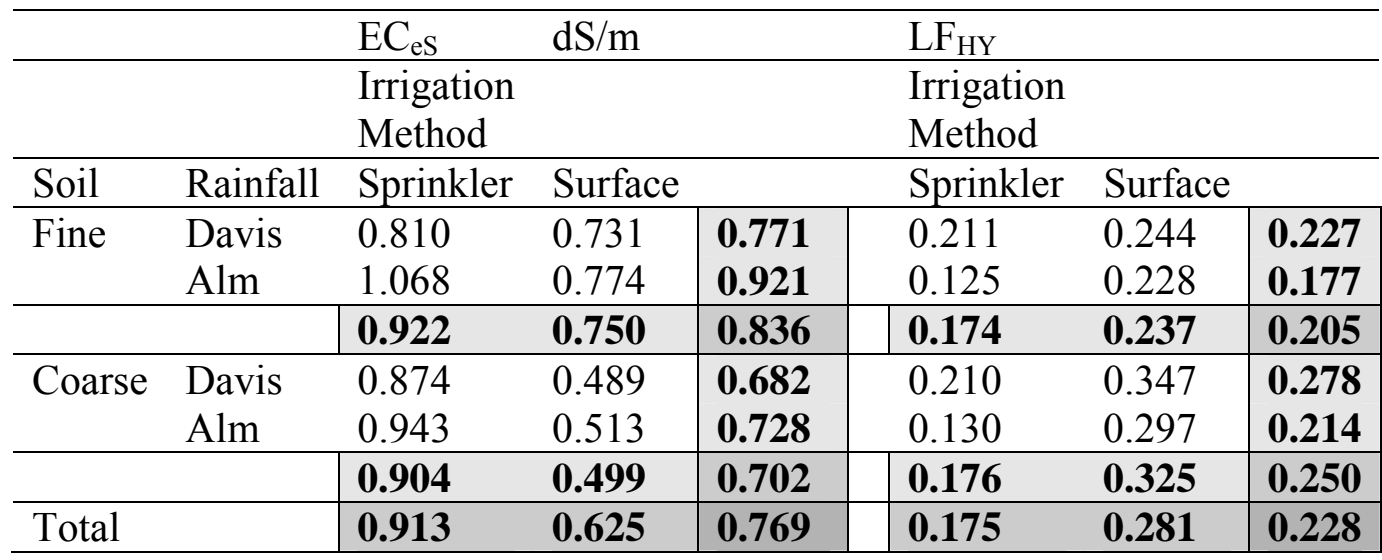

The winter-concentrated rainfall (Davis) was more effective in reducing $\mathrm{EC}_{\mathrm{e}}$, than when a similar amount of rainfall is distributed more evenly throughout the year. The model results indicate that the $\mathrm{EC}_{\mathrm{eS}}$ for Davis conditions were lower than those for Almudévar (and the leaching fraction higher) for all scenarios (Table 3). But the effect of the fixed-scheduled surface irrigation in lieu of sprinkler irrigation was more conspicuous (higher differences in Table 3) especially for the coarser-textured soil Hst.

The mean $\mathrm{EC}_{\mathrm{es}}$ for the different scenarios (Table 3) do not provide information about the actual distribution of the record of $\mathrm{EC}_{\mathrm{eS}}$ within each scenario or the differences between the distributions in each scenario. The mean $\mathrm{EC}_{\mathrm{eS}}$ were higher for the Almudévar series [Table 3; Fig. 5(b)] but it showed the highest values for the Davis rainfall series and soil Cc [Fig. 5(a)] because of the more skewed distribution of yearly rainfall in Davis (presenting some very low minimum values causing the highest $\mathrm{EC}_{\mathrm{es}}$ records).

\section{Factors affecting the EC $\underline{\underline{S}}$}

The $\mathrm{EC}_{\mathrm{es}}$ was not significantly related to the total rainfall or the mass of salts leached during the season, but was strongly related to their annual series (Table 4). Although the $\mathrm{EC}_{\mathrm{es}}$ was strongly related to the seasonal D and LF, the correlations were higher (in absolute value) with the annual D and LF (Table 4).

These correlations were different for the different scenarios, though the signs of the coefficients and the general pattern agreed with the general correlations in Table 4. For the Almudévar rain series, the correlations between $\mathrm{EC}_{\mathrm{eS}}$ and Salt and $\mathrm{P}$ during the season were significant $(\mathrm{P}<0.05)$ since most of the leaching took place during the season (Table 2$)$. 
Table 4 Coefficients of correlation (r) for all the years simulated between the mean electrical conductivity of the saturated paste extract $\left(\mathrm{EC}_{\mathrm{e}}\right)$ during the growing season $\left(\mathrm{EC}_{\mathrm{eS}}\right)$ and the volume of drainage (D), the mass of salts leached (Salt), the leaching fraction (LF), real evapotranspiration $\left(\mathrm{ET}_{\mathrm{r}}\right)$, and rainfall $(\mathrm{P})$ during both the season (Season) and the hydrologic year $(\mathrm{HY})$; and the irrigation $(\mathrm{I}), \mathrm{EC}_{\mathrm{e}}$ at the beginning of the season $\left(\mathrm{EC}_{\mathrm{oS}}\right)$ and the mean $\mathrm{EC}_{\mathrm{e}}$ for the whole hydrologic year $\left(\mathrm{EC}_{\mathrm{eHY}}\right)$

\begin{tabular}{lllll}
\hline & \multicolumn{2}{c}{$\mathrm{r}$} & & $\mathrm{r}$ \\
Variable & \multicolumn{1}{c}{ Season } & $\mathrm{HY}$ & Variable & \\
\hline $\mathrm{D}$ & -0.46 & -0.79 & $\mathrm{I}$ & -0.33 \\
Salt & $-0.04^{\mathrm{NS}}$ & -0.55 & $\mathrm{EC}_{\mathrm{oS}}$ & 0.89 \\
$\mathrm{LF}$ & -0.50 & -0.85 & $\mathrm{EC}_{\mathrm{eHY}}$ & 0.94 \\
$\mathrm{P}$ & $0.03^{\mathrm{NS}}$ & -0.60 & & \\
$\mathrm{ET}_{\mathrm{r}}$ & 0.40 & 0.15 & & \\
${ }_{\mathrm{NS}}$ not significant $(\mathrm{P}>0.05)$ & &
\end{tabular}

In all scenarios, as well as for the overall data there were well-defined relationships between $\mathrm{EC}_{\mathrm{eS}}$ and the rainfall of the hydrologic year $\left(\mathrm{P}_{\mathrm{HY}}\right)$, the leaching fraction for the hydrologic year $\left(\mathrm{LF}_{\mathrm{HY}}\right)$, and the $\mathrm{EC}_{\mathrm{e}}$ at the beginning of the irrigation season $\left(\mathrm{EC}_{\mathrm{oS}}\right)$. The correlation between $\mathrm{EC}_{\mathrm{eS}}$ and the $\mathrm{LF}$ for the irrigation season $\left(\mathrm{LF}_{\mathrm{S}}\right)$ was low $(\mathrm{r}=-0.50$; Table 4$)$, a finding that is inconsistent with the traditional assumption that $\mathrm{EC}_{\mathrm{eS}}$ responds to the $\mathrm{LF}_{\mathrm{S}}$.

The $\mathrm{EC}_{\mathrm{eS}}$ was also better correlated to the hydrologic year precipitation (i.e. the $\mathrm{EC}_{\mathrm{e}}$ of the growing season: May to September was related to $\mathrm{P}$ of the hydrologic year: October previous year to September) in Davis $(\mathrm{r}=-0.66, \mathrm{P}<0.001)$ than in Almudévar $(\mathrm{r}=-0.52, \mathrm{P}<0.001)$ due to the higher winter rain in Davis (Fig. 6). The relationships for Almudévar were weak, while in Davis they could foretell $\mathrm{EC}_{\mathrm{es}}$ quite accurately through a multiplicative model, though the parameters of the regressions were significantly different for each scenario (Table 5). In Davis, the $\mathrm{EC}_{\mathrm{eS}}$ could also be predicted from the $\mathrm{P}$ of the non-growing season (October previous year to April) quiet accurately.

For all the available data, $\mathrm{EC}_{\mathrm{eS}}$ was estimated from $\mathrm{LF}_{\mathrm{HY}}$ as $\mathrm{EC}_{\mathrm{eS}}=0.25 \cdot \mathrm{LF}_{\mathrm{HY}}{ }^{-0.641}$ $\left(\mathrm{R}^{2}=0.89 ; \mathrm{s}=0.15 ; \mathrm{N}=396\right)$. Assuming a potential relationship between the ratio $\mathrm{EC}_{\mathrm{eS}} / \mathrm{EC}_{\mathrm{w}}$ and the leaching fraction this equation translates into $\mathrm{EC}_{\mathrm{eS}} / \mathrm{EC}_{\mathrm{w}}=0.36 \cdot \mathrm{LF}_{\mathrm{HY}}{ }^{-0.641}$, different from the FAO equation below (Rhoades et al. 1992) in the coefficients and in the predictive variable $\left(\mathrm{LF}_{\mathrm{HY}}\right.$ instead of $\left.\mathrm{LF}_{\mathrm{S}}\right)$. The parameters of this relationship were significantly different for each scenario and yielded different equations relating $\mathrm{EC}_{\mathrm{eS}}$ to $\mathrm{LF}_{\mathrm{HY}}$ generally better in each scenario (Table 5). 

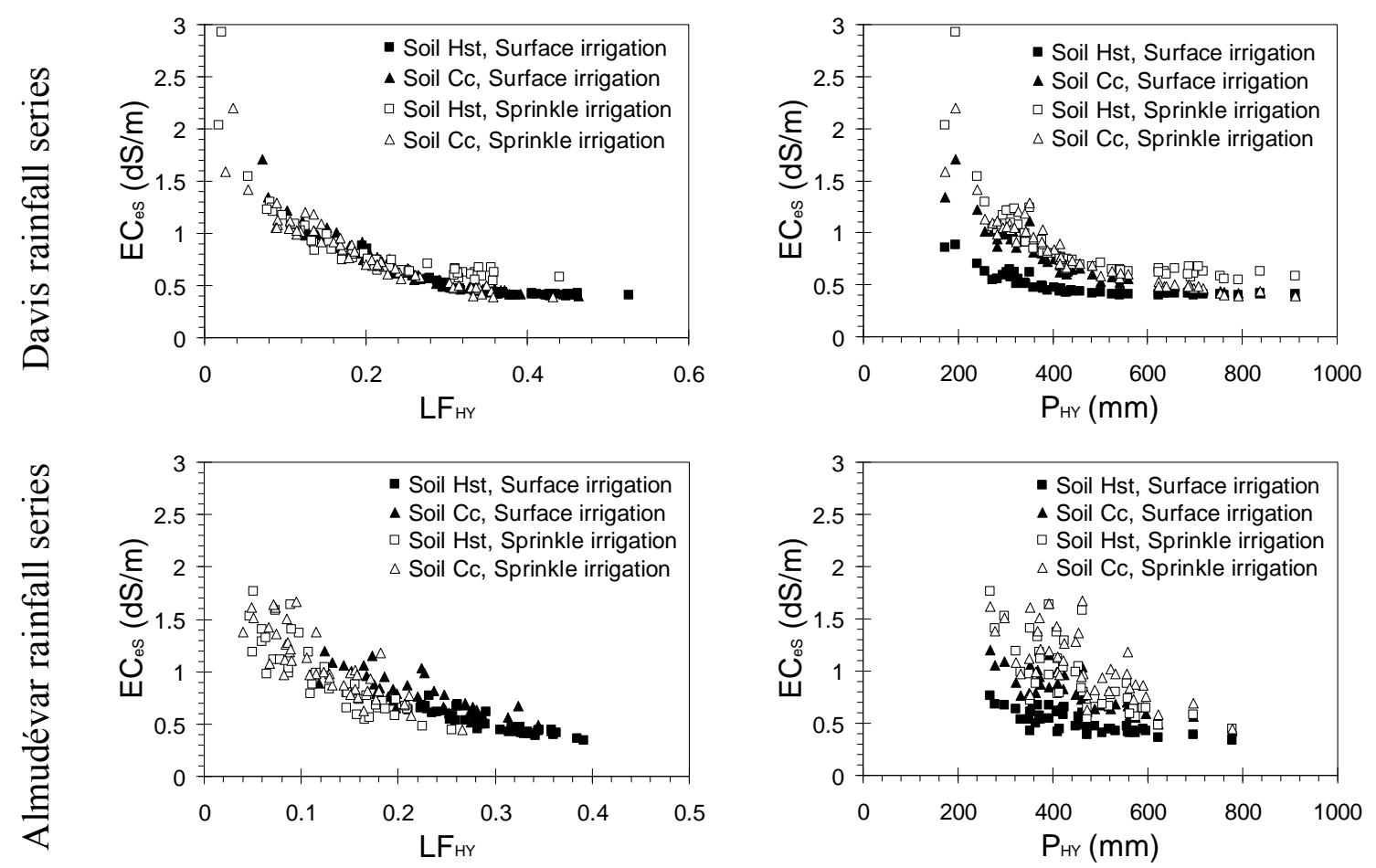

Fig. 6 Electrical conductivity of the saturated paste extract during the growing season $\left(\mathrm{EC}_{\mathrm{eS}}\right)$ versus the leaching fraction $\left(\mathrm{LF}_{\mathrm{HY}}\right)$ and the rainfall $\left(\mathrm{P}_{\mathrm{HY}}\right)$ of the hydrologic year for the 8 scenarios considered

The differences between the parameters of the $\mathrm{EC}_{\mathrm{eS}}-\mathrm{LF}_{\mathrm{HY}}$ (like the $\mathrm{EC}_{\mathrm{eS}}-\mathrm{P}_{\mathrm{HY}}$ ) relationships for each scenario were investigated by the linear regressions between their logarithms. The slopes of the relationships $\mathrm{EC}_{\mathrm{eS}}-\mathrm{LF}_{\mathrm{HY}}$ were not different for the 2 soil types or rainfall series (but the intercepts were), with $\mathrm{EC}_{\mathrm{eS}}$ higher for sprinkler irrigation and fine-textured soil than for surface irrigation and coarse-textured soil, but the response of both soils and irrigation types to growing $\mathrm{LF}_{\mathrm{HY}}$ were similar (equal slopes). The response to irrigation method was just the opposite: the intercepts were not significantly different but slopes were, with a steeper response for surface irrigation (Table 5).

The response of $\mathrm{EC}_{\mathrm{eS}}$ to $\mathrm{LF}_{\mathrm{HY}}$ was steeper for surface irrigation with fixed schedules (higher b) than for sprinkler irrigation. In Davis, where the winter rains are more concentrated, the statistical fits of $\mathrm{LF}_{\mathrm{HY}}$ and $\mathrm{P}_{\mathrm{HY}}$ with $\mathrm{EC}_{\mathrm{eS}}$ were better (higher $\mathrm{R}^{2}$ and lower $s$ ) than for the same irrigation method and soil type for the Almudévar series. The parameters (A and b) of the regressions $\mathrm{EC}_{\mathrm{eS}}-\mathrm{P}_{\mathrm{HY}}$ were more variable and did not show any clear pattern among the scenarios. 
Table 5 Parameters of the multiplicative regressions $\left(\mathrm{EC}_{\mathrm{eS}}=\mathrm{A} \cdot \mathrm{x}^{\mathrm{b}}\right)$ between the mean seasonal electrical conductivity of the saturated paste extract $\left(\mathrm{EC}_{\mathrm{eS}}\right)$ and the leaching fraction $\left(\mathrm{x}=\mathrm{LF}_{\mathrm{HY}}\right)$ or the precipitation $\left(\mathrm{x}=\mathrm{P}_{\mathrm{HY}}\right)$ of the hydrologic year fitted for each scenario [irrigation method: Sprinkler or Surface; Rainfall series: Davis or Almudévar (Alm) and Soil type: Fine or Coarse textured] and statistics of the regressions: coefficient of determination $\left(\mathrm{R}^{2}\right)$, standard error of the estimate (s) and number of observations (n)

\begin{tabular}{|c|c|c|c|c|c|c|c|}
\hline \multicolumn{8}{|c|}{ Leaching fraction of the hydrologic year $\left(\mathrm{LF}_{\mathrm{HY}}\right)$} \\
\hline Method & Rain & Soil & $\mathrm{A}$ & $\mathrm{b}$ & $\mathrm{R}^{2}$ & $\mathrm{~s}$ & $\mathrm{n}$ \\
\hline \multirow{4}{*}{ Sprinkler } & \multirow{2}{*}{ Davis } & Fine & 0.25 & -0.640 & 0.90 & 0.13 & 55 \\
\hline & & Coarse & 0.35 & -0.497 & 0.95 & 0.08 & 55 \\
\hline & \multirow{2}{*}{ Alm } & Fine & 0.30 & -0.569 & 0.69 & 0.17 & 42 \\
\hline & & Coarse & 0.21 & -0.677 & 0.78 & 0.17 & 42 \\
\hline \multirow{4}{*}{ Surface } & \multirow{2}{*}{ Davis } & Fine & 0.20 & -0.809 & 0.97 & 0.06 & 55 \\
\hline & & Coarse & 0.21 & -0.749 & 0.86 & 0.07 & 55 \\
\hline & \multirow{2}{*}{ Alm } & Fine & 0.24 & -0.759 & 0.72 & 0.13 & 42 \\
\hline & & Coarse & 0.13 & -1.131 & 0.83 & 0.08 & 42 \\
\hline \multicolumn{8}{|c|}{ Precipitation of the hydrologic year $\left(\mathrm{P}_{\mathrm{HY}}\right)$} \\
\hline Method & Rain & Soil & $\mathrm{A}$ & $\mathrm{b}$ & $\mathrm{R}^{2}$ & $\mathrm{~S}$ & $\mathrm{n}$ \\
\hline \multirow{4}{*}{ Sprinkle } & \multirow{2}{*}{ Davis } & Fine & 336.0 & -1.00 & 0.93 & 0.10 & 55 \\
\hline & & Coarse & 99.8 & -0.78 & 0.81 & 0.15 & 55 \\
\hline & \multirow{2}{*}{ Alm } & Fine & 210.3 & -0.87 & 0.49 & 0.22 & 42 \\
\hline & & Coarse & 7.0 & -1.16 & 0.62 & 0.17 & 42 \\
\hline \multirow{4}{*}{ Surface } & \multirow{2}{*}{ Davis } & Fine & 5.0 & -0.01 & 0.94 & 0.09 & 55 \\
\hline & & Coarse & 6.7 & -0.43 & 0.77 & 0.09 & 55 \\
\hline & \multirow{2}{*}{ Alm } & Fine & 104.3 & -0.81 & 0.63 & 0.15 & 42 \\
\hline & & Coarse & 29.3 & -0.67 & 0.65 & 0.12 & 42 \\
\hline
\end{tabular}

The poor relationship between $\mathrm{EC}_{\mathrm{eS}}$ and seasonal $\mathrm{LF}\left(\mathrm{LF}_{\mathrm{S}}\right)$ is largely explained by the different salinity levels at the beginning of the season $\left(\mathrm{EC}_{\mathrm{oS}}\right)$. The multiple regression of the $\mathrm{LF}_{\mathrm{S}}$ with the $\mathrm{EC}_{\mathrm{oS}}$ and $\mathrm{EC}_{\mathrm{eS}}$ for all the available data $\left(\mathrm{R}^{2}=0.60 ; \mathrm{s}=0.065 ; \mathrm{n}=396\right)$ was calculated to provide a tool for estimating the leaching requirement (LR) given the soil water salinity at the beginning of the season $\left(\mathrm{EC}_{\mathrm{oS}}\right.$, measured in the field) and the required soil salinity during the season $\left(\mathrm{EC}_{\mathrm{e}-\mathrm{req}}\right.$, determined by the crop and the expected yield): $\mathrm{LR}=0.379-0.507 \cdot \mathrm{EC}_{\mathrm{e}-\mathrm{req}}+0.330 \cdot \mathrm{EC}_{\mathrm{oS}}$ where the $\mathrm{EC}$ values are in $\mathrm{dS} / \mathrm{m}$ and the $\mathrm{LR}$ is a fraction. However, this relationship was calculated with $\mathrm{EC}_{\mathrm{w}}=0.7 \mathrm{dS} / \mathrm{m}$; and specific relationships should be calculated for different $\mathrm{EC}_{\mathrm{w}}$. The scenario-specific relationships between these parameters resulted in better fits (but do not provide a unique general equation for the LR).

The $\mathrm{EC}_{\mathrm{eS}}-\mathrm{LF}_{\mathrm{S}}$ relationship is also affected by the differences in the early and late season soil water contents. In all the scenarios the mean change in the water content along the season was negative, with mean water depletion throughout the growing season of $26 \mathrm{~mm}$. In only 
53 out of the 396 simulations did the soil water content increase along the season. The mean seasonal soil water depletion was significantly higher for the Davis $(33 \mathrm{~mm})$ than the Alm rain series $(18 \mathrm{~mm})$ in the mean (also for each soil-method combination) due to the higher soil water recharge in Davis series during the winter and leading to the poorer $\mathrm{EC}_{\mathrm{eS}}-\mathrm{LF}_{\mathrm{S}}$ relationship for Davis. The differences in the seasonal soil water depletion between the rain series were higher for the Spr case than for the Surf case in soil Cc (with higher TAW) but very similar in soil Hst, due to its lower TAW.

\section{Comparison with FAO 29}

One of the goals for developing this model was to expand upon the FAO 29 approach to account for temporal variability in rainfall and irrigation, as well as soil water dynamics, although the differences between both approaches make any comparison difficult. The $\mathrm{EC}_{\mathrm{eS}}$ series obtained with the model were compared with the results of the FAO formula $\mathrm{EC}_{\mathrm{eS}} / \mathrm{EC}_{\mathrm{w}}=0.501 \cdot \mathrm{LF}_{\mathrm{S}}^{-0.5875}$ (Rhoades et al., 1992) used for conventional (low frequency) irrigation. With the FAO approach, the $\mathrm{EC}_{\mathrm{eS}}$ is calculated only from the seasonal $\mathrm{LF}$ not including rainfall during the winter. Therefore the $\mathrm{FAO}$ estimates for $\mathrm{EC}_{\mathrm{eS}} / \mathrm{EC}_{\mathrm{w}}$ were calculated with the LF of the growing season ( $\mathrm{LF}_{\mathrm{S}}$ calculated by the model for every season) and the mean weighted EC of the seasonal irrigation and precipitation: $\mathrm{EC}_{\mathrm{w}-\mathrm{p}}=\left(\mathrm{EC}_{\mathrm{w}} \cdot \mathrm{I}+\mathrm{EC}_{\mathrm{p}} \cdot \mathrm{P}\right) /(\mathrm{I}+\mathrm{P})($ Fig. 7). When the model is used with no rainfall, the resulting $\mathrm{EC}_{\mathrm{eS}}$ is higher than $\mathrm{EC}_{\mathrm{e}}$ calculated by the steady state $\mathrm{FAO}$ approach (data not shown) suggesting that other factors considered (time distribution of rain and irrigation, actual water extraction pattern, and soil properties) and not rainfall alone, produce the lower-than-FAO approach model estimates below.

For the Davis rainfall series, the model $\mathrm{EC}_{\mathrm{eS}}$ estimates were lower than the $\mathrm{FAO} \mathrm{EC}_{\mathrm{eS}}$ estimates $\left(\mathrm{EC}_{\mathrm{e}-\mathrm{FAO}}\right)$ for both methods of irrigation and soils except in a few, very dry years [Fig. 7(a)]. For the Almudévar rainfall series, the model $\mathrm{EC}_{\mathrm{eS}}$ estimates were closer to the $\mathrm{EC}_{\mathrm{e}-\mathrm{FAO}}$; relationship but only for surface irrigation on soil $\mathrm{Cc}$, the $\mathrm{EC}_{\mathrm{eS}}$ was higher than $\mathrm{EC}_{\mathrm{e}}$ FAO more often than not. Also, only for this scenario were the paired differences $\mathrm{EC}_{\mathrm{es}}-\mathrm{EC}_{\mathrm{e}}$ FAO positive and significantly different form $0(\mathrm{P}<0.05)$ (i.e., the model provided higher salinity, more conservative estimates than the FAO formula) [Fig. 7(b)]. For all other scenarios the paired differences $\mathrm{EC}_{\mathrm{eS}}-\mathrm{EC}_{\mathrm{e}-\mathrm{FAO}}$ were negative and significantly different form $0(\mathrm{P}<0.05)$ : the FAO estimates were more conservative than the model estimates. Thus, the FAO formula estimates were generally more conservative (i.e., higher predicted $\mathrm{EC}_{\mathrm{eS}}$ ) than the model estimates, especially under winter rain conditions in the Davis location. 

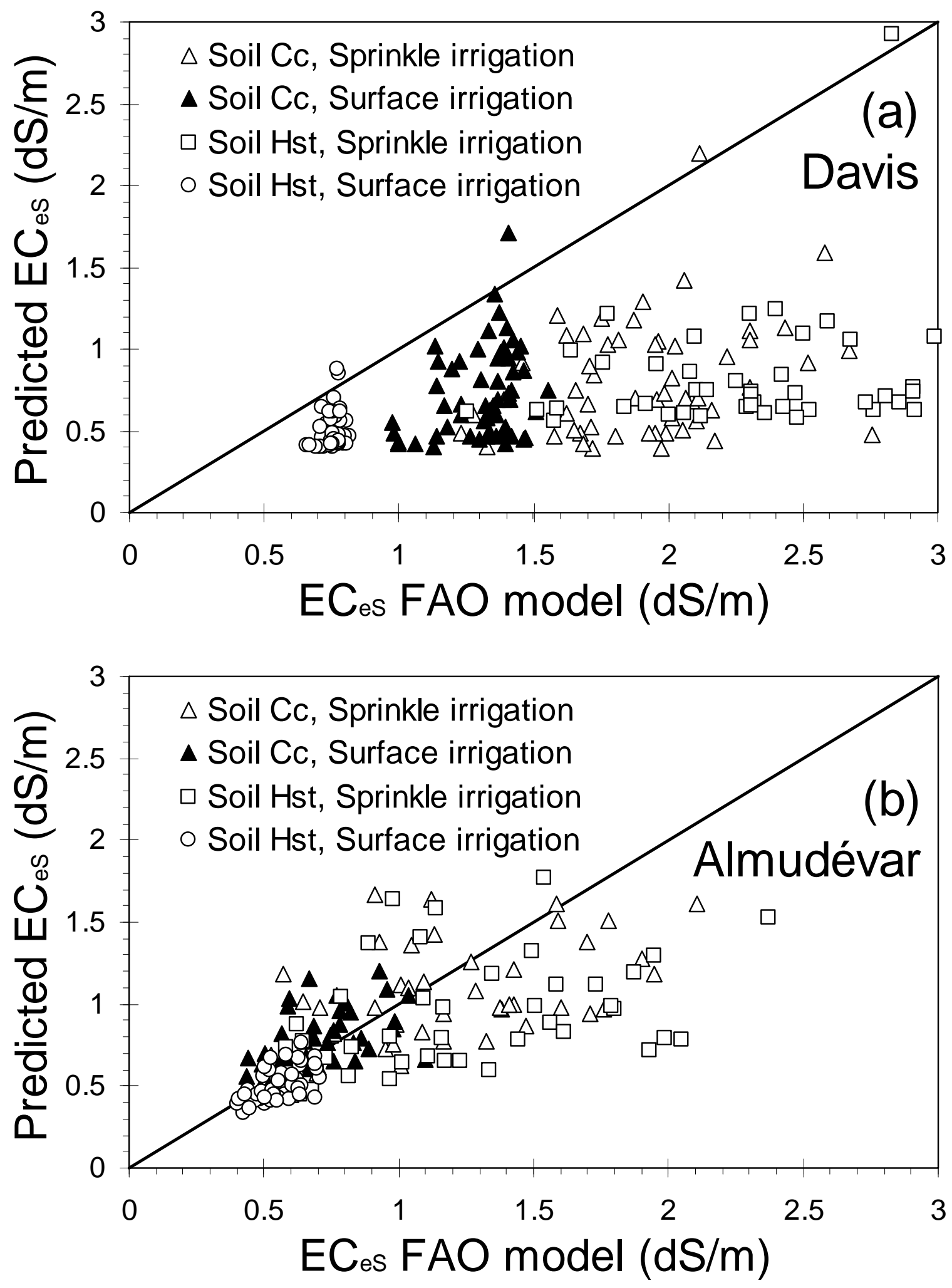

Fig. 7 Mean electrical conductivity of the saturated paste extract during the growing season $\left(\mathrm{EC}_{\mathrm{eS}}\right)$ predicted by the model versus the $\mathrm{EC}_{\mathrm{es}}$ predicted by the $\mathrm{FAO}$ formulae for all the scenarios considered with the Davis (a) and Almudévar (b) rainfall series

The mean ratios $\mathrm{EC}_{\mathrm{eS}} / \mathrm{EC}_{\mathrm{w}}$ (where $\mathrm{EC}_{\mathrm{w}}=0.7 \mathrm{dS} / \mathrm{m}$ ) for each scenario were clearly related to the LF for the hydrologic year $\left(\mathrm{LF}_{\mathrm{HY}}\right)$ but not the seasonal LF $\left(\mathrm{LF}_{\mathrm{S}}\right)$ (Fig. 8). The relationship 
$\mathrm{EC}_{\mathrm{eS}} / \mathrm{EC}_{\mathrm{w}}-\mathrm{LF}_{\mathrm{HY}}$ was approximately linear [Fig 8(a)], showing that increasing $\mathrm{LF}_{\mathrm{HY}}$ reduced $\mathrm{EC}_{\mathrm{eS}}$ regardless of the scenario considered. However, the good potential fits between $\mathrm{EC}_{\mathrm{eS}}$ and $\mathrm{LF}_{\mathrm{HY}}$ for each scenario (especially for the Davis series, Table 5) point to the convenience of using specific (irrigation, soil type and rainfall series) relationships to establish $\mathrm{EC}_{\mathrm{eS}}$ from $\mathrm{LF}_{\mathrm{HY}}$ when possible. For a given soil and irrigation method, the $\mathrm{LF}_{\mathrm{HY}}$ was always higher and the ratio $\mathrm{EC}_{\mathrm{eS}} / \mathrm{EC}_{\mathrm{w}}$ lower for the Davis than the Almudévar rain series. The smallest differences between the Davis and Almudévar rainfall series are found f/or surface irrigation on soil Cc and the highest for the sprinkler method on both soils [Fig. 8(a)].

The mean ratio $\mathrm{EC}_{\mathrm{eS}} / \mathrm{EC}_{\mathrm{w}}$ was closer to the $\mathrm{FAO}$ estimate from seasonal $\mathrm{LF}$ for the Alm rainfall series scenarios, although only for the surface irrigation method and soil Cc was it higher. For all the scenarios with the Dav rainfall series, the ratio $\mathrm{EC}_{\mathrm{eS}} / \mathrm{EC}_{\mathrm{w}}$ was much lower than the FAO estimate [Fig. 8(b)]. Different $\mathrm{EC}_{\mathrm{eS}} / \mathrm{EC}_{\mathrm{w}}-\mathrm{LF}_{\mathrm{S}}$ relationships could be established for the Davis and Almudévar series [with lower $\mathrm{EC}_{\mathrm{eS}} / \mathrm{EC}_{\mathrm{w}}$ and better fit for the Davis series, Fig. 8(b)], though the number of scenarios considered did not provide enough simulations to assure this behavior. 

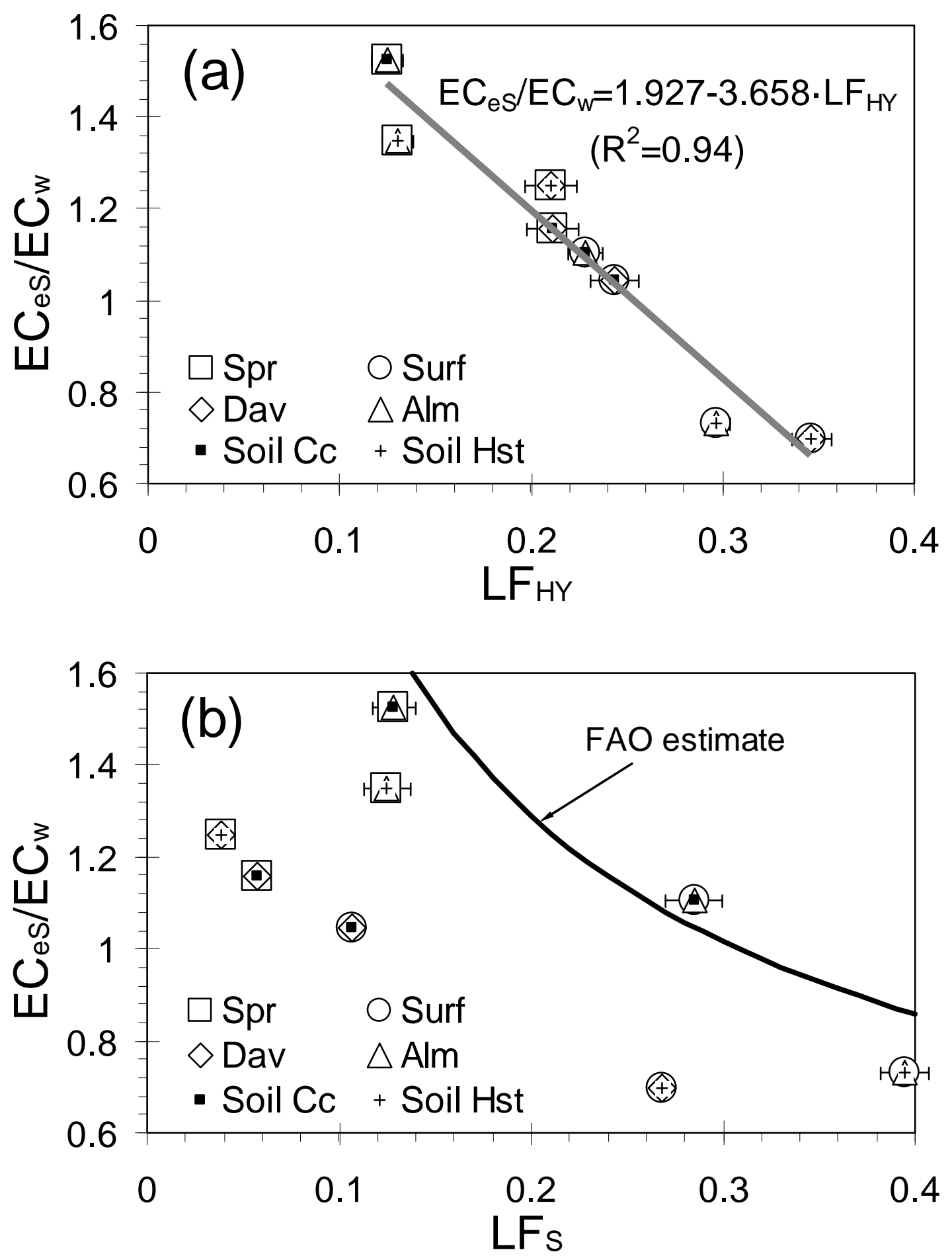

Fig. 8 Ratio of the mean electrical conductivity (EC) during the growing season $\left(\mathrm{EC}_{\mathrm{eS}}\right)$ to the $\mathrm{EC}$ of the irrigation water $\left(\mathrm{EC}_{\mathrm{w}}=0.7 \mathrm{dS} / \mathrm{m}\right)$ as related to the leaching fraction during the hydrologic year $\left(\mathrm{LF}_{\mathrm{HY}}\right)$ and the irrigation season $\left(\mathrm{LF}_{\mathrm{S}}\right)$ for all the scenarios [Type of irrigation: sprinkle (Spr) or surface (Surf); Rainfall series: Davis (Dav) or Almudévar (Alm) and Soil series: Capay $(\mathrm{Cc})$ or Hesperia (Hst)]. The bars represent one standard error of mean in each scenario (the standard errors of the ratio $\mathrm{EC}_{\mathrm{eS}} / \mathrm{EC}_{\mathrm{w}}$ were too low to be shown) 


\section{Conclusions}

The model presented here was able to evaluate the differences in soil salinity induced by different rainfall patterns (winter concentrated or year distributed), methods of irrigation (sprinkler and surface with a fixed number of irrigations) and soils (with different total available water, TAW) over a long record of meteorological data. Although the general behavior of soil salinity under these conditions could be outlined by the model, a thorough model evaluation and validation process with a comprehensive set of soil salinity data and daily inputs in the field would be needed to assess the salinity resulting form these scenarios and to determine other factors affecting it. Nevertheless, this model sheds light on a number of relationships that could have a profound influence on predicting soil salinity. Therefore until validation, this model should be used conceptually as a management tool to understand how the soil textural-class and daily inputs (such as rainfall distribution) influence rootzone salinity both within and outside the growing season.

The mean seasonal $\mathrm{EC}$ of the saturated paste extract $\left(\mathrm{EC}_{\mathrm{eS}}\right.$, the variable usually related to crop yield) was found to vary widely for the rainfall series, management practices and soil types considered: (i) Surface irrigation produced lower $\mathrm{EC}_{\mathrm{eS}}$ and higher leaching fraction than sprinkler irrigation though it also led to higher ET deficit in the lower TAW soil; (ii) The winter concentrated rainfall series produced lower $\mathrm{EC}_{\mathrm{eS}}$ than the series where rainfall was distributed more or less evenly throughout the year; and (iii) The higher TAW soil resulted in higher $\mathrm{EC}_{\mathrm{eS}}$, except for sprinkler irrigation combined with winter rain. These results indicate the importance of the irrigation method, rainfall distribution (particularly disproportional distributions) and soil water holding characteristics for determining the $\mathrm{EC}_{\mathrm{eS}}$. Considering these site specific (meteorological, soil and irrigation management) features could help improve the estimation of the leaching requirements and the allowable salinity of the irrigation water for the protection of crop production.

The $\mathrm{EC}_{\mathrm{eS}}$ could be predicted from the hydrologic year rainfall $\left(\mathrm{P}_{\mathrm{HY}}\right)$ and leaching fraction $\left(\mathrm{LF}_{\mathrm{HY}}\right)$ by regression; but not from the seasonal leaching fraction $\left(\mathrm{LF}_{\mathrm{S}}\right)$ as assumed by the traditional FAO approach. Also, these regressions were different for each scenario; showing again the need to account for rainfall distribution, soil properties and type of irrigation to determine soil salinity. The $\mathrm{EC}_{\mathrm{es}}$ predicted by the model was lower than the $\mathrm{EC}_{\mathrm{es}}$ estimated by the traditional FAO approach, except for surface irrigation with year-through rainfall on the higher TAW soil. This suggests that the widely used FAO steady-state rules for soil salinity and leaching requirement estimation could be improved, particularly if knowledge of 
site-specific conditions exists. The traditional FAO assumptions led to higher salinity than that predicted by the model particularly when rainfall occurs primarily in winter months, emphasizing the importance of winter leaching as an important factor to be considered in the determination of the $\mathrm{EC}_{\mathrm{eS}}$. If the model results were validated, the use of site specific information would result in lower leaching requirements or higher allowable irrigation water salinity; thus allowing for reducing the amount of water needed for irrigation or for the use of more saline waters for irrigation.

\section{Acknowledgements}

Emilio Collados of the Agencia Estatal de Meteorología (Zaragoza) facilitated the rainfall series for Almudévar.

\section{References}

Allen RG, Pereira LS, Raes D, Smith M (1998) Crop evapotranspiration-guidelines for computing cropwater requirements. FAO 56, Rome

Ashton WD (1972) The logit transformation with special reference to its uses in bioassay. Hafner Publ Co, New York

Ayers RS, Westcot DW (1985) Water quality for agriculture. FAO 29 Rev 1, Rome.

Bastiaansen WGM, Allen RG, Droogers P, D’Urso G, Steduto P (2007) Twenty-five years modeling irrigated and drained soils: State of the art. Agric Water Manage 92:111125

Clapp RB, Hornberger GM (1978) Empirical equations for some soil hydraulic properties. Water Resour Res 14(4):601-604

Corwin DL, Rhoades JD, Šimunek J (2007) Leaching requirements for soil salinity control: Steady-state versus transient models. Agric Water Manage 90:165-180

Doorenbos J, Kassam, AH (1979) Yield response to water. FAO 33, Rome.

Goldhamer DA, Snyder RL (1989) Irrigation scheduling: A guide for efficient on-farm water management. University of California, Division of Agriculture and Natural Resources Publication 21454

Hanson B, Schwankl L, Grattan S, Prichard T (1996) Drip irrigation for row crops. Division of agriculture and natural resources Publication 3376, University of California Irrigation Program, University of California, Davis

Hargreaves GH, Allen RG (2003) History and evaluation of Hargreaves evapotranspiration equation. J Irrig Drain Eng 129(1):53-63

Hillel D and van Bavel CHM (1976) Simulation of profile water storage as related to soil hydraulic properties. Soil Sci Soc Am J 40(6):807-815

Letey J, Feng GL (2007) Dynamic versus steady-state approaches to evaluate irrigation management of saline waters. Agr. Water Manage. 91:1-10 
National Atmospheric Deposition Program (2005) NADP/NTN Monitoring Location CA88. In: National Atmospheric Deposition Program. Available via DIALOG http://nadp.sws.uiuc.edu/. Accessed 15 June 2009

National Resources Conservation Service (1968) Soil Survey of Yolo County, California. In: National Resources Conservation Service. Available via DIALOG http://www.ca.nrcs.usda.gov/mlra02/yolo/. Accessed 20 Apr 2009

National Climate Data Center (2004) California weather database: DAVIS.C (NCDC \#2294, Davis). In: UC IPM Online statewide integrated pest management program. Available via DIALOG http://www.ipm.ucdavis.edu/WEATHER/wxretrieve.html. Accessed 20 June 2009

Ongley ED (1996) Control of water pollution from agriculture. FAO 55, Rome.

Rawls WJ, Brakensiek DL (1989) Estimation of soil water retention and hydraulic properties. In: Morel-Seytoux HJ (ed), Proceedings of the NATO Advanced Research Workshop on Unsaturated Flow in Hydrologic Modeling Theory and Practice (1988, Arles, France, NATO ASI series, Series C, Mathematical and physical sciences no 275. Kluwer Academic Publishers), pp 275-300

Rhoades JD, Kandiah A, Mashali AM (1992) The use of saline waters for crop production, FAO 48, Rome

Skaggs RW, van Shilfgaarde J (1999) Agricutltural drainage, ASA-CSSA-SSSA Agronomy no 38 , Madison

Tanji KK, Kielen NC (2002) Agricultural drainage water management in arid and semi-arid areas. FAO 61, Rome 